Check for updates

Cite this: RSC Adv., 2018, 8, 28810

\title{
Anticancer activities of a $\beta$-amino alcohol ligand and nanoparticles of its copper(II) and zinc(II) complexes evaluated by experimental and theoretical methods $\uparrow$
}

\author{
Zahra Mardani, (D) *a Reza Kazemshoar-Duzduzani, ${ }^{a}$ Keyvan Moeini, (DD ${ }^{\mathrm{b}}$ \\ Alireza Hajabbas-Farshchi, (ID c Cameron Carpenter-Warren, ${ }^{d}$ \\ Alexandra M. Z. Slawin (D) ${ }^{d}$ and J. Derek Woollins ${ }^{d}$
}

2-(2-(2-Hydroxyethylamino)ethylamino)cyclohexanol (HEAC) and copper and zinc complexes, [Cu(HEAC) $\mathrm{Cl}] \mathrm{Cl}$ (1), [Cu(HEAC)Br]Br (2), [Zn(HEAC)Cl $]$ (3), were prepared and identified by elemental analysis, FT-IR, UV-Vis, ${ }^{1} \mathrm{H}$ NMR spectroscopy and single-crystal X-ray diffraction. Also nanoparticles of 1-3 were prepared for anticancer studies by ultrasonic irradiation. Particle size and morphology of the nano particles are investigated by PXRD and SEM, respectively. X-ray analysis revealed that the ionic complexes 1 and 2 are isostructural. In the structure of complexes 1 and 2, the metal atom has a $\mathrm{CuN}_{2} \mathrm{O}_{2} \mathrm{X}(\mathrm{X}: \mathrm{Cl}$ (1), $\mathrm{Br}(2))$ environment with square-pyramidal geometry, containing the tetradentate $\mathrm{N}_{2} \mathrm{O}_{2}$-donor HEAC. The bond length of the axial position in the square-pyramidal geometry of 1 and 2 is elongated. Complex 3 has a $\mathrm{ZnN}_{2} \mathrm{OCl}_{2}$ environment with trigonal bipyramidal geometry around the zinc atom in which the HEAC acts as mer- $\mathrm{N}_{2} \mathrm{O}$-donor. The ability of $\mathrm{HEAC}$ and nano particles $1-3$ to interact with the nine biomacromolecules (BRAF kinase, CatB, DNA gyrase, HDAC7, rHA, RNR, TrxR, TS and Top II) are investigated by docking calculations. For examination of the docking results, the in vitro activities of four compounds against the human leukemia cell line $\mathrm{K} 562$ were investigated by evaluation of $I_{50}$ values and mode of cell death (apoptosis). The thermodynamic stability of the compounds along with the charge distribution pattern were studied by DFT and NBO analysis, respectively.

Received 29th May 2018

Accepted 7th August 2018

DOI: $10.1039 / \mathrm{c} 8 \mathrm{ra04578j}$

rsc.li/rsc-advances organocatalysts. ${ }^{\mathbf{1 0}}$ Amino alcohols such as mono- and diethanolamine are known to fix $\mathrm{CO}_{2}$ and are used as absorbents for the chemical absorption of $\mathrm{CO}_{2} \cdot{ }^{11-13}$ The interactions of this class of compounds toward DNA and proteins have been established by docking studies. ${ }^{\mathbf{1 4 , 1 5}}$

As a result, a number of synthetic methods have been developed, including asymmetric reduction of $\alpha$-amino carbonyl compounds ${ }^{16}$ or $\alpha$-hydroxy carbonyl compounds, ${ }^{17}$ asymmetric amino hydroxylation of olefins ${ }^{18}$ asymmetric hydroboration of enamines ${ }^{\mathbf{1 9}}$ and ring opening of epoxides by amines. ${ }^{20}$ The last method has been developed through the use of different heterogeneous catalysts. ${ }^{21}$ Also the tandem reduction and ring-opening reaction of nitroarenes and epoxides has been reported. ${ }^{22}$

Because of the interesting chemistry of $\beta$-amino alcohols, this work describes the preparation, characterization, crystal structure and theoretical study of three new complexes, $[\mathrm{Cu}(\mathrm{HEAC}) \mathrm{Cl}] \mathrm{Cl}$ (1), [Cu(HEAC)Br]Br (2), [Zn(HEAC)Cl 2$]$ (3), with 2-((2-((2-hydroxyethyl)amino)ethyl)amino)cyclohexan-1-ol (HEAC, Scheme 1). In addition to the expected biological properties of the $\beta$-amino alcohols derivatives, ${ }^{\mathbf{1 - 4}}$ binding the copper and zinc atoms to this unit make these complexes a good 


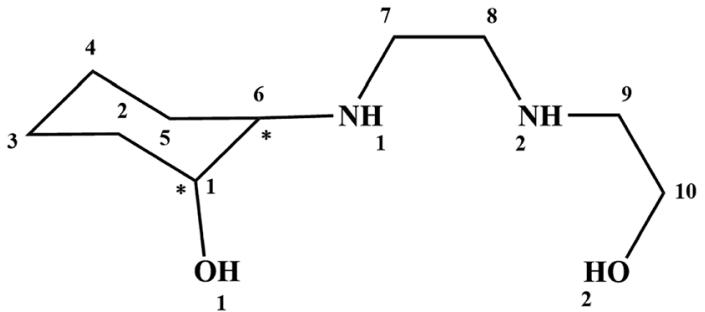

Scheme 1 The structure of the 2-(2-(2-hydroxyethylamino)ethylamino)cyclohexanol (HEAC).

choice for biologically active compounds. ${ }^{23-25}$ For studying the biological activities of the title compounds, a docking calculation was run to investigate the possibility of interactions between HEAC and its copper and zinc complexes with nine protein targets $^{26}$ including, BRAF kinase, cathepsin B (CatB), DNA gyrase, histone deacetylase (HDAC7), recombinant human albumin (rHA), ribonucleotide reductases (RNR), thioredoxin reductase (TrxR), thymidylate synthase (TS), topoisomerase II (Top II). These proteins are used in this project either due to their reported roles in cancer growth or as transport agents that affect drug pharmacokinetic properties (e.g., rHA). Also, DNA gyrase was included to study of the possibility of anticancer properties also acting as antimalarial agents. ${ }^{27}$

The nano particles 1-3 were papered by ultrasonic irradiation to study the anticancer potential, mode of cell death and apoptosis on the K562 cell lines. Similar studies were performed on HEAC to determine the effect of coordination on the ligand anticancer activity. The K562 cell line is a pluripotent precursor cell that is positive for the Philadelphia ( $\mathrm{Ph}$ ) chromosome and was originally derived from a patient with human chronic myelogenous leukemia (CML) at the terminal stage of last crisis; this cell line is non-adherent and rounded, highly undifferentiated with an active proliferative capacity and the inhibition of apoptosis. $^{28}$

\section{Experimental}

\subsection{Materials and instrumentation}

All starting chemicals and solvents were reagent or analytical grade and used as received. The HEAC ligand has been synthesized according to the literature. ${ }^{29}$ The infrared spectra of $\mathrm{KBr}$ pellets in the range $4000-400 \mathrm{~cm}^{-1}$ were recorded with a FTIR TENSOR 27 spectrometer. ${ }^{1} \mathrm{H}$ NMR spectra were recorded on Bruker Aspect 3000 instrument. The carbon, hydrogen and nitrogen contents were determined by a Thermo Finnigan Flash Elemental Analyzer 1112 EA. The melting points were determined with a Barnsted Electrothermal 9200 electrically heated apparatus. The ultrasonic-assisted reaction was carried out using an ultrasonic bath - Sonica 2200ETH S3-Soltec. The electronic spectra were recorded in $\mathrm{H}_{2} \mathrm{O}$ using a Shimadzu model 2550 UV-Vis spectrophotometer (190-900 nm). The PXRD patterns were recorded using X'PertPro diffractometer (Holland) with CuK $\propto 1$ radiation $(k=1.54056 \AA)$. An accelerating voltage of $40 \mathrm{kV}$ and an emission current of $30 \mathrm{~mA}$ were used. SEM images are recorded by scanning electron microscope (TSCAN, Czechoslovakia).
2.1.1. Synthesis of [Cu(HEAC)Cl]Cl (1). A solution of $0.20 \mathrm{~g}$ $(1 \mathrm{mmol})$ of HEAC, dissolved in methanol $(10 \mathrm{~mL})$, was added to a stirring solution containing of $\mathrm{CuCl}_{2} \cdot 2 \mathrm{H}_{2} \mathrm{O}(0.17 \mathrm{~g}, 1 \mathrm{mmol})$ in methanol $(10 \mathrm{~mL})$. The reaction mixture was stirred for five days at $60{ }^{\circ} \mathrm{C}$ and then filtered. Suitable blue prisms were obtained for X-ray diffraction studies by slow evaporation of the solution for a week and collection by filtration. Yield: $0.11 \mathrm{~g}, 33 \%$; $\mathrm{mp}$ $189{ }^{\circ} \mathrm{C}$. Anal. calcd for $\mathrm{C}_{10} \mathrm{H}_{22} \mathrm{Cl}_{2} \mathrm{CuN}_{2} \mathrm{O}_{2}$ (\%): C, 35.67; H, 6.59; N, 8.32. Found: C, 35.42; H, 6.86; N, 8.41. IR ( $\left.\mathrm{KBr}, \mathrm{cm}^{-1}\right)$ : $3255(\nu \mathrm{O}-\mathrm{H}), 3150(\nu \mathrm{N}-\mathrm{H}), 2935\left(\nu \mathrm{C}-\mathrm{H}\right.$ and/or $\left.\nu_{\text {as }} \mathrm{CH}_{2}\right), 2886\left(\nu_{\mathrm{s}}\right.$ $\left.\mathrm{CH}_{2}\right), 1451\left(\delta_{\text {as }} \mathrm{CH}_{2}\right), 1331\left(\delta_{\mathrm{s}} \mathrm{CH}_{2}\right), 1249$ and $1210(\nu \mathrm{C}-\mathrm{O}), 1103$ $(\nu \mathrm{C}-\mathrm{N})$. UV-Vis $\left(\mathrm{H}_{2} \mathrm{O}, \lambda_{\max }(\mathrm{nm}) / \varepsilon\right): 679 / 80(\mathrm{~d} \rightarrow \mathrm{d})$.

2.1.1.1. Synthesis of nano particles of [Cu(HEAC)Cl]Cl (1). HEAC (0.69 g, $3.4 \mathrm{mmol})$ and $\mathrm{CuCl}_{2} \cdot 2 \mathrm{H}_{2} \mathrm{O}(0.58 \mathrm{~g}, 3.4 \mathrm{mmol})$ were separately dissolved in ethanol $(20 \mathrm{~mL})$, and were irradiated inside an ultrasonic bath for 20 minutes at room temperature. The ligand solution was added to the metallic solution before being sonicated for 30 minutes and removing the solvent by rotary evaporation. Finally, the product was formed and collected. Yield: $0.52 \mathrm{~g}, 45 \%$; mp $189{ }^{\circ} \mathrm{C}$. Anal. calcd for $\mathrm{C}_{10^{-}}$ $\mathrm{H}_{22} \mathrm{Cl}_{2} \mathrm{CuN}_{2} \mathrm{O}_{2}$ (\%): C, 35.67; H, 6.59; N, 8.32. Found: C, 35.48; $\mathrm{H}, 6.72 ; \mathrm{N}, 8.40$. IR ( $\left.\mathrm{KBr}, \mathrm{cm}^{-1}\right): 3257(\nu \mathrm{O}-\mathrm{H}), 3151(\nu \mathrm{N}-\mathrm{H})$, $2935\left(\nu \mathrm{C}-\mathrm{H}\right.$ and/or $\left.\nu_{\text {as }} \mathrm{CH}_{2}\right), 2886\left(\nu_{\mathrm{s}} \mathrm{CH}_{2}\right), 1451\left(\delta_{\text {as }} \mathrm{CH}_{2}\right), 1331$ $\left(\delta_{\mathrm{s}} \mathrm{CH}_{2}\right), 1249$ and $1211(\nu \mathrm{C}-\mathrm{O}), 1105(\nu \mathrm{C}-\mathrm{N})$.

2.1.2. Synthesis of $[\mathrm{Cu}(\mathrm{HEAC}) \mathrm{Br}] \mathrm{Br}$ (2). The procedure for the synthesis of 2 was similar to 1 except that the $\mathrm{CuCl}_{2} \cdot 2 \mathrm{H}_{2} \mathrm{O}$ was replaced by $\mathrm{CuBr}_{2}(0.22 \mathrm{~g}, 1 \mathrm{mmol})$. Suitable blue prisms for $\mathrm{X}$-ray diffraction studies were obtained by slow evaporation of the solution for a week and collected by filtration. Yield: $0.27 \mathrm{~g}$, $63 \%$; mp 180-184 ${ }^{\circ} \mathrm{C}$. Anal. calcd for $\mathrm{C}_{10} \mathrm{H}_{22} \mathrm{Br}_{2} \mathrm{CuN}_{2} \mathrm{O}_{2}$ (\%): C, 28.22; H, 5.21; N, 6.58. Found: C, 28.32; H, 5.20; N, 6.64. IR $\left(\mathrm{KBr}, \mathrm{cm}^{-1}\right): 3242(\nu \mathrm{O}-\mathrm{H}), 3200(\nu \mathrm{N}-\mathrm{H}), 2929\left(\nu \mathrm{C}-\mathrm{H}\right.$ and/or $\nu_{\text {as }}$ $\left.\mathrm{CH}_{2}\right), 2881\left(\nu_{\mathrm{s}} \mathrm{CH}_{2}\right), 1448\left(\delta_{\mathrm{as}} \mathrm{CH}_{2}\right), 1328\left(\delta_{\mathrm{s}} \mathrm{CH}_{2}\right), 1243$ and $1204(\nu \mathrm{C}-\mathrm{O}), 1100$ and $1050(\nu \mathrm{C}-\mathrm{N})$. UV-Vis $\left(\mathrm{H}_{2} \mathrm{O}, \lambda_{\max }(\mathrm{nm}) / \varepsilon\right)$ : $680 / 76(\mathrm{~d} \rightarrow \mathrm{d})$.

2.1.2.1. Synthesis of nano particles of $[\mathrm{Cu}(\mathrm{HEAC}) \mathrm{Br}] \mathrm{Br}$ (2). The procedure for the synthesis of nano particles 2 was similar to 1 except that the $\mathrm{CuCl}_{2} \cdot 2 \mathrm{H}_{2} \mathrm{O}$ was replaced by $\mathrm{CuBr}_{2}(0.76 \mathrm{~g}, 3.4$ mmol). Yield: $1.2 \mathrm{~g}, 83 \%$; mp $180-184{ }^{\circ} \mathrm{C}$. Anal. calcd for $\mathrm{C}_{10^{-}}$ $\mathrm{H}_{22} \mathrm{Br}_{2} \mathrm{CuN}_{2} \mathrm{O}_{2}$ (\%): C, 28.22; H, 5.21; N, 6.58. Found: C, 28.35; $\mathrm{H}, 5.26$; N, 6.60. IR ( KBr, cm $\left.{ }^{-1}\right): 3244(\nu \mathrm{O}-\mathrm{H}), 3200(\nu \mathrm{N}-\mathrm{H})$, $2930\left(\nu \mathrm{C}-\mathrm{H}\right.$ and/or $\left.\nu_{\text {as }} \mathrm{CH}_{2}\right), 2881\left(\nu_{\mathrm{s}} \mathrm{CH}_{2}\right), 1447\left(\delta_{\text {as }} \mathrm{CH}_{2}\right), 1328$ $\left(\delta_{\mathrm{s}} \mathrm{CH}_{2}\right), 1243$ and $1205(\nu \mathrm{C}-\mathrm{O}), 1100$ and $1050(\nu \mathrm{C}-\mathrm{N})$.

2.1.3. Synthesis of $\left[\mathrm{Zn}(\mathbf{H E A C}) \mathbf{C l}_{2}\right]$ (3). The procedure for synthesis of 3 was similar to 1 except that the $\mathrm{CuCl}_{2} \cdot 2 \mathrm{H}_{2} \mathrm{O}$ was replaced by $\mathrm{ZnCl}_{2}(0.14 \mathrm{~g}, 1 \mathrm{mmol})$. After evaporation of the solution, an oily product was formed which was dissolved in acetone $(5 \mathrm{~mL})$. Suitable colorless prisms for X-ray diffraction studies were obtained by evaporation of the solution and collection by filtration. Yield: $0.06 \mathrm{~g}, 18 \%$; mp $170-173{ }^{\circ} \mathrm{C}$. Anal. calcd for $\mathrm{C}_{10} \mathrm{H}_{21} \mathrm{Cl}_{2} \mathrm{~N}_{2} \mathrm{O}_{2} \mathrm{Zn}$ (\%): C, 35.58; H, 6.27; N, 8.30. Found: C, 35.59; H, 6.29; N, 8.43. IR (KBr, cm $\left.{ }^{-1}\right): 3429(\nu \mathrm{O}-\mathrm{H})$, $3200(\nu \mathrm{N}-\mathrm{H}), 2941\left(\nu \mathrm{C}-\mathrm{H}\right.$ and/or $\left.\nu_{\text {as }} \mathrm{CH}_{2}\right), 2865\left(\nu_{\mathrm{s}} \mathrm{CH}_{2}\right), 1458$ $\left(\delta_{\text {as }} \mathrm{CH}_{2}\right), 1387\left(\delta_{\mathrm{s}} \mathrm{CH}_{2}\right), 1202(\nu \mathrm{C}-\mathrm{O}), 1100$ and $1046(\nu \mathrm{C}-\mathrm{N}) \cdot{ }^{1} \mathrm{H}$ NMR (300 MHz, DMSO- $\left.d_{6}\right)$ : (5.8)s, $1 \mathrm{H}, \mathrm{O}^{1} \mathrm{H},(4.8) \mathrm{s}, 1 \mathrm{H}, \mathrm{O}^{2} \mathrm{H}$, (3.9)t, $2 \mathrm{H}, \mathrm{C}^{10} \mathrm{H}_{2},(3.4) \mathrm{m}, 1 \mathrm{H}, \mathrm{C}^{1} \mathrm{H},(2.6-3.3) \mathrm{m}, 6 \mathrm{H}, \mathrm{C}^{7} \mathrm{H}_{2}, \mathrm{C}^{8} \mathrm{H}_{2}$, 
$\mathrm{C}^{9} \mathrm{H}_{2},(2.5) \mathrm{m}, 1 \mathrm{H}, \mathrm{C}^{6} \mathrm{H},(2.4) \mathrm{s}, 2 \mathrm{H}, \mathrm{N}^{1} \mathrm{H}, \mathrm{N}^{2} \mathrm{H},(1.9-2.0) \mathrm{m}, 2 \mathrm{H}$, $\mathrm{C}^{2} \mathrm{H}_{2}$, (1.7)m, $2 \mathrm{H}, \mathrm{C}^{5} \mathrm{H}_{2}$, (1.2)m, $4 \mathrm{H}, \mathrm{C}^{4} \mathrm{H}_{2}, \mathrm{C}^{3} \mathrm{H}_{2}$.

2.1.3.1. Synthesis of nano particles of $\left[\mathrm{Zn}(\mathrm{HEAC}) \mathrm{Cl}_{2}\right]$ (3). The procedure for synthesis of nano particles 3 was similar to 1 except that the $\mathrm{CuCl}_{2} \cdot 2 \mathrm{H}_{2} \mathrm{O}$ was replaced by $\mathrm{ZnCl}_{2}(0.46 \mathrm{~g}, 3.4$ $\mathrm{mmol})$. After rotary evaporation, an oily product was formed which was dissolved in acetone $(15 \mathrm{~mL})$. The final product was formed after evaporation of acetone. Yield: $0.53 \mathrm{~g}, 46 \%$; $\mathrm{mp}$ 170-173 ${ }^{\circ} \mathrm{C}$. Anal. calcd for $\mathrm{C}_{10} \mathrm{H}_{21} \mathrm{Cl}_{2} \mathrm{~N}_{2} \mathrm{O}_{2} \mathrm{Zn}(\%): \mathrm{C}, 35.58 ; \mathrm{H}$, 6.27; N, 8.30. Found: C, 35.63; H, 6.30; N, 8.8.39.

\subsection{Crystal structure determination}

X-ray diffraction data for complexes 1 and 2 were collected at 93 K using a Rigaku FR-X Ultrahigh Brilliance Microfocus RA generator/confocal optics with XtaLAB P200 diffractometer. The data for complex 3 was collected at $173 \mathrm{~K}$ using a Rigaku SCXmini CCD diffractometer with a SHINE monochromator. Mo K $\alpha$ radiation $(\lambda=0.71075 \AA)$ was used for all the compounds and intensity data were collected using $\omega$ steps accumulating area detector images spanning at least a hemisphere of reciprocal space. All data were corrected for Lorentz polarization effects. A multiscan absorption correction was applied using CrystalClear. ${ }^{30}$ Structures were solved using dual space methods $\left(\right.$ SHELXT $\left.^{31}\right)$ and refined by full-matrix least-squares against $F^{2}$ (SHELXL-2013 (ref. 32)). Non-hydrogen atoms were refined anisotropically, and hydrogen atoms were refined using a riding model or freely for $\mathrm{N}-\mathrm{H}$ and $\mathrm{O}-\mathrm{H}$ atoms, with the exception of the $\mathrm{O}-\mathrm{H}$ groups on the disordered ethanolic groups of $\mathbf{3}$, these were assigned geometrically. All calculations were performed using the CrystalStructure interface. Selected crystallographic data are presented in Table 1. Diagrams of the molecular structure and unit cell were created using Ortep-III ${ }^{33,34}$ and Diamond. ${ }^{35}$ Selected bond lengths and angles are displayed in Table 2 and hydrogen bond geometries in Table 3.

\subsection{Computational details}

All structures were optimized with the Gaussian 09 software $^{36}$ and calculated for an isolated molecule using Density Functional Theory (DFT) ${ }^{37}$ at the B3LYP/LanL2DZ level of theory, as well as for NBO analysis. The cif file of the complexes were used as input files for the theoretical calculations.

\subsection{Docking details}

The pdb files 4r5y, 3ai8, 5cdn, 3c0z, 2bx8, 1peo, 3qfa, 1njb, 4gfh for the nine receptors, BRAF kinase, cathepsin B (CatB), DNA gyrase, histone deacetylase (HDAC7), recombinant human albumin ( $\mathrm{rHA}$ ), ribonucleotide reductases (RNR), thioredoxin reductase (TrxR), thymidylate synthase (TS), topoisomerase II (Top II), respectively, used in this research were obtained from the Protein Data Bank (pdb). ${ }^{38}$ The full version of Genetic Optimisation for Ligand Docking (GOLD) 5.5 (ref. 39) was used for the docking studies. The Hermes visualizer in the GOLD Suite was used to further prepare the metal complexes and the receptors for docking. The optimized HEAC ligand and cif files of the complexes were used for docking studies. The region of interest used for Gold docking was defined as all the protein residues within $6 \AA$ of the reference ligand " $\mathrm{A}$ " that accompanied the downloaded protein. All free water molecules in the

Table 1 Crystal data and structure refinement for complexes 1-3

\begin{tabular}{|c|c|c|c|}
\hline & 1 & 2 & 3 \\
\hline Empirical formula & $\mathrm{C}_{10} \mathrm{H}_{22} \mathrm{Cl}_{2} \mathrm{CuN}_{2} \mathrm{O}_{2}$ & $\mathrm{C}_{10} \mathrm{H}_{22} \mathrm{Br}_{2} \mathrm{CuN}_{2} \mathrm{O}_{2}$ & $\mathrm{C}_{10} \mathrm{H}_{22} \mathrm{Cl}_{2} \mathrm{~N}_{2} \mathrm{O}_{2} \mathrm{Zn}$ \\
\hline Formula weight, $\mathrm{g} \mathrm{mol} \mathrm{m}^{-1}$ & 336.75 & 425.65 & 338.58 \\
\hline Crystal size, $\mathrm{mm}$ & $0.21 \times 0.14 \times 0.05$ & $0.18 \times 0.12 \times 0.06$ & $0.15 \times 0.09 \times 0.050$ \\
\hline Temperature, $\mathrm{K}$ & 93 & 93 & 173 \\
\hline Crystal system & Orthorhombic & Orthorhombic & Monoclinic \\
\hline Space group & Pbca & Pbca & $P 2_{1} / c$ \\
\hline \multicolumn{4}{|l|}{ Unit cell dimensions } \\
\hline$a, \AA$ & $6.63584(15)$ & $6.68836(15)$ & $10.3713(8)$ \\
\hline$b, \AA$ & $11.8221(3)$ & $12.3506(3)$ & $12.4965(9)$ \\
\hline$c, \AA$ & $34.9929(8)$ & $35.1567(8)$ & 11.9806(9) \\
\hline$\beta, \circ$ & 90 & 90 & $94.277(8)$ \\
\hline Volume, $\AA^{3}$ & $2745.18(11)$ & $2904.13(12)$ & $1548.4(2)$ \\
\hline$Z$ & 8 & 8 & 4 \\
\hline Calculated density, $\mathrm{g} \mathrm{cm}^{-3}$ & 1.629 & 1.947 & 1.452 \\
\hline Absorption coefficient, $\mathrm{mm}^{-1}$ & 1.972 & 7.017 & 1.924 \\
\hline$F(000), \mathrm{e}$ & 1400.00 & 1688.00 & 704.00 \\
\hline$\theta$ range for data collection, ${ }^{\circ}$ & $2.3-28.4$ & $2.3-28.4$ & $2.4-25.4$ \\
\hline$h, k, l$ ranges & $\begin{array}{l}-8 \leq h \leq 8,-15 \leq k \leq 15 \\
-45 \leq l \leq 46\end{array}$ & $\begin{array}{l}-8 \leq h \leq 8,-15 \leq k \leq 16 \\
-44 \leq l \leq 46\end{array}$ & $\begin{array}{l}-12 \leq h \leq 12,-15 \leq k \leq 15 \\
-14 \leq l \leq 14\end{array}$ \\
\hline Reflections collected/independent $/ R_{\text {int }}$ & $57562 / 3242 / 0.084$ & $61924 / 3452 / 0.056$ & 12 999/2830/0.187 \\
\hline Data/restraints/parameters & $3242 / 4 / 170$ & $3452 / 4 / 170$ & $2830 / 2 / 188$ \\
\hline Goodness-of-fit on $F^{2}$ & 1.25 & 1.06 & 0.834 \\
\hline$R_{1} / \mathrm{w} R_{2}(I \geq 2 \sigma(I))$ & $0.0721 / 0.1834$ & $0.0206 / 0.0535$ & $0.0504 / 0.1154$ \\
\hline$R_{1} / \mathrm{w} R_{2}$ (all data) & $0.0793 / 0.1862$ & $0.0236 / 0.0543$ & $0.0957 / 0.1293$ \\
\hline Largest diff. peak/hole, e $\AA^{-3}$ & $3.52 /-0.93$ & $0.68 /-0.45$ & $0.80 /-0.55$ \\
\hline
\end{tabular}


Table 2 Selected bond length $(\AA)$ and angles $\left({ }^{\circ}\right)$ for complexes 1-3 with estimated standard deviations in parentheses

$1 \quad 2$

$\begin{array}{lr}\text { Distances } & \\ \text { Cu1-Cl1 } & 2.2533(15) \\ \text { Cu1-Cl2 } & 4.538(2) \\ \text { Cu1-N1 } & 2.028(5) \\ \text { Cu1-N5 } & 2.010(5) \\ \text { Cu1-O2 } & 2.243(4) \\ \text { Cu1-O10 } & 2.012(4) \\ & \\ \text { Angles } & \\ \text { Cl1-Cu1-O2 } & 97.74(12) \\ \text { Cl1-Cu1-N1 } & 96.54(15) \\ \text { O2-Cu1-O10 } & 92.52(17) \\ \text { O2-Cu1-N5 } & 102.09(18) \\ \text { O10-Cu1-N5 } & 82.16(19) \\ \text { Cl1-Cu1-O10 } & 98.58(13) \\ \text { Cl1-Cu1-N5 } & 160.11(15) \\ \text { O2-Cu1-N1 } & 81.27(18) \\ \text { O10-Cu1-N1 } & 164.31(19) \\ \text { N1-Cu1-N5 } & 85.1(2)\end{array}$

Cu1-Br1
Cu1-Br2
Cu1-N1
Cu1-N5
Cu1-O2
Cu1-O10

$\mathrm{Br} 1-\mathrm{Cu} 1-\mathrm{O} 2$

Br1-Cu1-N1

O2-Cu1-O10

O2-Cu1-N5

O10-Cu1-N5

Br1-Cu1-O10

Br1-Cu1-N5

O2-Cu1-N1

O10-Cu1-N1

N1-Cu1-N5
3

$2.3974(3)$
$4.6567(6)$
$2.0194(16)$
$2.0098(17)$
$2.2384(14)$
$2.0039(14)$

$98.53(4)$
$96.49(5)$
$92.13(6)$
$103.08(6)$
$82.47(6)$
$97.97(4)$
$158.36(5)$
$81.15(6)$
$164.81(6)$
$85.80(7)$
Zn1-Cl1

$\mathrm{Zn} 1-\mathrm{Cl} 2$

Zn1-N1

Zn1-N5

$\mathrm{Zn1-O10}$

2.2431(14)

2.2953(14)

2.151(5)

$2.069(4)$

2.303(4) structure of the proteins were deleted before docking. Default values for all other parameters were used and the complexes were submitted to 10 genetic algorithm runs using the GOLDScore fitness function.

\subsection{Biological evaluation}

2.5.1. Materials. Fetal bovine serum (FBS), propidium iodide (PI), acridine orange (AO) and 3-(4,5-dimethylthiazol-2yl)-2,5-diphenyl tetrazolium bromide (MTT) were obtained from Sigma Aldrich. RPMI-1640 medium was obtained from Gibco (UK). Dimethyl sulfoxide (DMSO) was obtained from Merck. Fluorescent studies were done by fluorescent microscope (OLYMPUS, USA).

2.5.2. Cell culture and treatments. Human leukemia cell line K562 and its adriamycin-selected multidrug resistant

Table 3 Hydrogen bonds dimensions $\left(\AA\right.$ and $\left.{ }^{\circ}\right)$ in complexes 1-3

\begin{tabular}{lllll}
\hline $\mathrm{D}-\mathrm{H} \cdots \mathrm{A}$ & $d(\mathrm{D}-\mathrm{H})$ & $d(\mathrm{H} \cdots \mathrm{A})$ & $\angle(\mathrm{DHA})$ & $d(\mathrm{D} \cdots \mathrm{A})$ \\
\hline $\mathbf{1}$ & & & & \\
$\mathrm{O}(2)-\mathrm{H}(2) \cdots \mathrm{Cl}(2)$ & $0.98(2)$ & $2.04(3)$ & $164(6)$ & $2.994(4)$ \\
$\mathrm{O}(10)-\mathrm{H}(10) \cdots \mathrm{Cl}(2)$ & $0.97(2)$ & $2.18(5)$ & $145(6)$ & $3.025(4)$ \\
$\mathrm{N}(1)-\mathrm{H}(1) \cdots \mathrm{Cl}(1)$ & $0.96(2)$ & $2.69(3)$ & $164(6)$ & $3.623(5)$ \\
$\mathrm{N}(5)-\mathrm{H}(5) \cdots \mathrm{Cl}(2)$ & $0.99(2)$ & $2.35(3)$ & $165(6)$ & $3.314(5)$ \\
& & & & \\
2 & & & & \\
$\mathrm{O}(2)-\mathrm{H}(2) \cdots \mathrm{Br}(2)$ & $0.932(18)$ & $2.230(19)$ & $172(3)$ & $3.1552(14)$ \\
$\mathrm{O}(10)-\mathrm{H}(10) \cdots \mathrm{Br}(2)$ & $0.947(18)$ & $2.251(19)$ & $165(3)$ & $3.1759(14)$ \\
$\mathrm{N}(1)-\mathrm{H}(1) \cdots \mathrm{Br}(1)$ & $0.920(16)$ & $2.840(17)$ & $165(2)$ & $3.7349(16)$ \\
$\mathrm{N}(5)-\mathrm{H}(5) \cdots \mathrm{Br}(2)$ & $0.940(17)$ & $2.548(18)$ & $166(2)$ & $3.4675(17)$ \\
& & & & \\
3 & & & & \\
$\mathrm{~N}(1)-\mathrm{H}(1) \cdots \mathrm{Cl}(2)$ & $0.978(10)$ & $2.48(2)$ & $153(4)$ & $3.378(4)$ \\
$\mathrm{N}(5)-\mathrm{H}(5) \cdots \mathrm{Cl}(2)$ & $0.979(10)$ & $2.338(17)$ & $164(4)$ & $3.288(4)$ \\
$\mathrm{O}(10)-\mathrm{H}(10) \cdots \mathrm{Cl}(1)$ & $0.973(10)$ & $2.24(2)$ & $161(5)$ & $3.181(4)$ \\
$\mathrm{O}(2 \mathrm{~A})-\mathrm{H} 2 \mathrm{E} \cdots \mathrm{Cl}(2)$ & 0.98 & 2.73 & 139.7 & $3.539(9)$
\end{tabular}

subline K562/ADM were obtained from the Pasteur Institute of Iran. All the cell lines were grown in RPMI 1640 medium containing $10 \%$ fetal bovine serum (FBS) and penicillin (100 U $\left.\mathrm{mL}^{-1}\right)$ and streptomycin $(100 \mu \mathrm{g})$ (BIOCERA) at $37{ }^{\circ} \mathrm{C}$ in a humidified $5 \% \mathrm{CO}_{2}$ incubator. To maintain MDR phenotype, adriamycin $\left(1 \mathrm{mg} \mathrm{L}^{-1}\right)$ was added to K562/ADM cultures and maintained in the drug-free medium for at least two weeks before being used. Compounds were dissolved in of DMSO (180 $\mu \mathrm{L}$ ) for in vitro assays.

2.5.3. The MTT assay. Cells were cultured at a density of 1 $\times 10^{4} / 100 \mu \mathrm{L}$ in a 96-well plate and allowed to attach overnight. After the incubation with the testing chemicals for $48 \mathrm{~h}$ and $72 \mathrm{~h}$, the cells were treated with the solution of MTT $(5 \mathrm{mg}$ $\mathrm{mL}^{-1}$ ) at $37^{\circ} \mathrm{C}$ for $4 \mathrm{~h}$. The absorbance was measured at $498 \mathrm{~nm}$ using a microplate reader (Multiskan Spectrum, Thermo Scientific). The inhibition rates were calculated on a plate-byplate basis for the test wells. The $\mathrm{IC}_{50}$ values were calculated based on the inhibitory rate curves using Bliss' method.

2.5.4. AO/PI staining assay. After treatment for $24 \mathrm{~h}$ with the compounds, the K562 cells were harvested, centrifuged at $400 \mathrm{rpm}$ for $10 \mathrm{~min}$ and then washed in PBS. Then $1 \mathrm{~mL}$ aliquots were incubated in the dark with $\mathrm{AO}(10 \mu \mathrm{L})$ and PI $(10$ $\mu \mathrm{L})$ for $15 \mathrm{~min}$. After mixing the suspension with a solution of $\mathrm{AO} / \mathrm{PI}$, analysis was performed under a fluorescence microscope. Whilst a green fluorescence showed apoptosis, a red colored nucleus indicated necrotic cells.

\section{Results and discussion}

Reaction between HEAC and methanolic solution of the copper(II) chloride, copper(II) bromide and zinc(II) chloride provides complexes 1-3, respectively. The complexes are air-stable and soluble in DMF, DMSO and $\mathrm{H}_{2} \mathrm{O}$. In all CSD searches which have been presented, for more precise results, the structures containing any error or disorder have been omitted. 


\subsection{Spectroscopic characterization}

The frequency of IR bands for the free ligand are different from those of the corresponding complexes, providing significant indications of bonding sites of the HEAC. In the IR spectrum of HEAC, a broad peak at $3267 \mathrm{~cm}^{-1}$ can be assigned to the $(\nu \mathrm{O}-\mathrm{H})$ which is shifted about 12 and $25 \mathrm{~cm}^{-1}$ to lower frequencies in complexes 1 and 2, respectively, whilst in $\mathbf{3}$ the peak is shifted to higher frequency than that of the free ligand $\left(162 \mathrm{~cm}^{-1}\right)$. Another peak above the $3000 \mathrm{~cm}^{-1}$ is corresponding to the stretching vibration of the amine groups of the ligand. Comparison of the IR spectra of the compounds revealed that the $\nu(\mathrm{N}-\mathrm{H})$ is shifted to a higher frequency $(53,103$ and $103 \mathrm{~cm}^{-1}$ in $1-3$, respectively) which can be attributed to the coordination of these groups to the metal centers. Also the bands in the range of $2800-3000 \mathrm{~cm}^{-1}$, which can be assigned to the asymmetric and symmetric stretching vibrations of the $\mathrm{C}-\mathrm{H}$ bonds, confirm the presence of the aliphatic moieties in the studied compounds.

In the ${ }^{1} \mathrm{H}$ NMR spectrum of complex 3 (see Scheme 1 for numbering), the peaks corresponding to the hydrogen atoms of the two alcohol groups of HEAC are observed at the lowest magnetic field. The proton on the cyclohexane alcohol group shifts about 1 ppm to a lower magnetic field, with respect to the free ligand, ${ }^{\mathbf{4 0}}$ revealing the coordination through this moiety whilst protons on the ethanolic arm do not undergo a significant shift. Another interesting part of this spectrum is the shifts of the amine groups to predict the coordination behavior of the HEAC. The peaks of amine protons are shifted by $0.3 \mathrm{ppm}$ to a lower magnetic field after coordination. Based on this data we can conclude that the $\mathrm{HEAC}$ acts as $\mathrm{N}_{2} \mathrm{O}$-donor toward the zinc atom.

UV-Vis spectra of the complexes 1 and 2 in aqueous solution exhibited a broad absorption which was assigned to the d$d$ transition of the copper(II) complexes. The energy for the $d-$ $\mathrm{d}$ transition in the two complexes is very similar (679 and $680 \mathrm{~nm}$ for 1 and 2 respectively), showing that the HEAC ligand has a more significant effect on the ligand field strength than the coordinated halide ions.

\subsection{Description of the crystal structures}

3.2.1. Crystal structure of $[\mathrm{Cu}(\mathrm{HEAC}) \mathrm{Cl}] \mathrm{Cl}$ (1). X-ray analysis of complex $\mathbf{1}$ (Fig. 1) revealed a five coordinate $\mathrm{Cu}$ (II) center bound to the tetradentate HEAC ligand and one chloro ligand, with one chloride anion per copper center to balance charge. The nature of penta-coordinate geometry can be assessed by applying the formula proposed by Addison et al. ${ }^{\mathbf{4 1 , 4 2}}$ The angular structural parameter, $\tau(\tau=(\beta-\alpha) / 60$, where $\alpha$ and $\beta$ are the two largest angles at the copper atom with $\beta \geq \alpha$ ), was calculated to be 0.07 indicating a slightly distorted square-pyramidal geometry around the copper atom (Fig. 1 and 2). In this geometry, the oxygen atom of the ethanolic arm occupies the axial position whilst the cyclohexanolic oxygen and two amine nitrogen atoms lie on the equatorial plane along with the chloro ligand. The axial $\mathrm{Cu}-\mathrm{O}$ bond distance is 0.231 (4) A longer than the equatorial $\mathrm{Cu}-\mathrm{O}$, showing an elongated bond length down the $z$-axis, consistent with pseudo Jahn-Teller distortions observed in

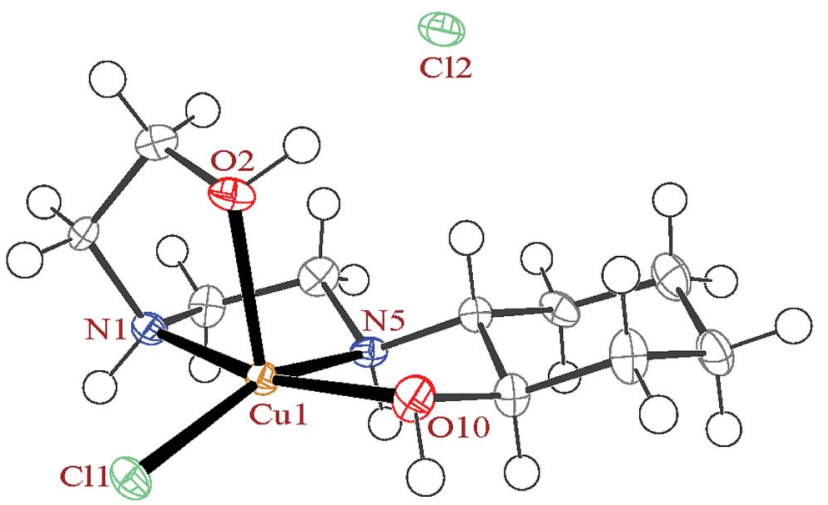

Fig. 1 The ortep diagram of the molecular structure of the complex 1. The ellipsoids are drawn at the $50 \%$ probability level.

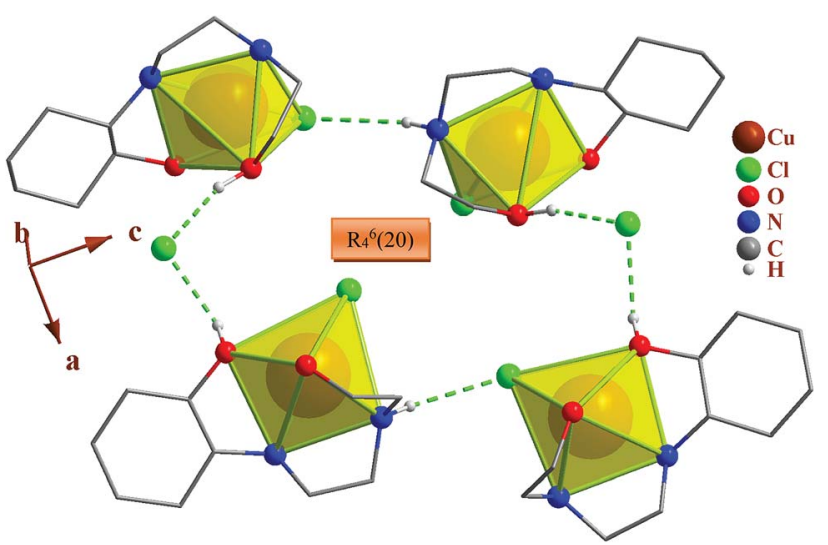

Fig. 2 Packing of the complex 1, showing the hydrogen bonds. Only the hydrogen atoms involved in hydrogen bonding are shown. Each $\mathrm{CuN}_{2} \mathrm{O}_{2} \mathrm{Cl}$ unit is shown as square-pyramid. Also $\mathrm{R}_{4}^{6}(20)$ hydrogen bond motifs between four complexes 1 is shown.

other $\mathrm{Cu}(\mathrm{II})$ square pyramidal structures. ${ }^{43}$ For comparing the geometrical parameters of $\mathbf{1}$ with the Cambridge Structural Database (CSD), ${ }^{44}$ a search was run on all analogues of $\mathbf{1}$ (all structures containing the base presented in Scheme 2; the macrocyclic ligands have been deleted for more precise results). Based on this study, a tetradentate ligand coordinated to a copper(II) center containing a chloro ligand commonly form with square-pyramidal geometry (81\%) (Fig. 3). These squarepyramidal complexes can be further subdivided into two categories: where the chloro ligand can be either axial (Scheme 2(a)) or equatorial (Scheme 2(b)). The percentage of the structures containing the axial chloro ligand (59\%) is higher than the equatorial variant. The average $\mathrm{Cu}-\mathrm{Cl}$ distance in the structures containing axial chloro ligand is $0.271 \AA$ longer than the equatorial variant (Scheme 2), confirming the presence of elongation of the bond in the axial direction. In complex $\mathbf{1}$, the chloro ligand is located in the equatorial plane with a bond length of 2.2533(15) $\AA$ which is comparable to the CSD average (Scheme 2(b)). The $\mathrm{Cu}-\mathrm{Cl}$ bond length average of the complexes with trigonal bipyramidal geometry is similar to the squarepyramidal complexes containing a chloro ligand in the equatorial position. 
In the crystal structure of $\mathbf{1}$, the geometry around the copper atom is square-pyramidal. Is this geometry common for the penta-coordinated copper atom? For answering this question, all $\mathrm{CN}=5$ copper complexes deposited in the CSD were analyzed by the Addison formula and results are shown in Fig. 4. Based on this study, common geometry around the copper atom in penta-coordinated complexes is squarepyramidal (88\%), similarly in 1.

In complex 1, the HEAC ligand acts as a tetradentate $\mathrm{N}_{2} \mathrm{O}_{2}$ donor and forms three five-membered, non-planar chelate rings. The angle between the mean planes through the two equatorial chelate rings is $7.5(3)^{\circ}$, showing these two chelate rings are almost coplanar and also are perpendicular to the axial chelate ring (with angle of $86.8(2)^{\circ}$ between mean planes through the axial and equatorial chelate rings). The cyclohexane ring of the HEAC has a chair conformation and two of the carbon atoms are chiral with the same enantiomeric form. In addition, two new chiral centers are formed upon coordination (the nitrogen atoms) with different enantiomeric forms. Thus the complex has four chiral centers. However, the crystals overall contain a racemic mixture of $R, R, R, S$ and $S, S, S, R$ isomers in alternate layers. ${ }^{45,46}$

3.2.2. Crystal structure of $[\mathrm{Cu}(\mathrm{HEAC}) \mathrm{Br}] \mathrm{Br}(2)$. X-ray analysis of complex 2 (Fig. 5) revealed that the complex is the isostructural bromine analogue of $\mathbf{1}$. It exhibits a five coordinate $\mathrm{Cu}(\mathrm{II})$ center bound to the tetradentate HEAC ligand and one bromo ligand, with one bromine anion per copper center to balance charge. For $2, \tau=0.11$, which means that the geometry is still square-pyramidal, however the distortion is slightly greater than in $\mathbf{1}$. Similarly, to $\mathbf{1}$, the $\mathrm{Cu}-\mathrm{O}$ bond length of the oxygen atom on the ethanolic arm in the axial position is by0.2345(14) $\AA$ longer than the equatorial one. A structural study of the CSD revealed that there are four examples ${ }^{47-50}$ for base presented in Scheme 2, in which the chloride ion is replaced by a bromide ion (the macrocyclic ligands have been deleted for more precise results). Three of the structures have square-pyramidal geometry around the metal atom $(\tau=0.01-$ 0.35 (ref. 47-49)) and one of them has tetragonal bi pyramidal ( $\tau$ $=0.57$ (ref. 50)). The averages of the axial and equatorial $\mathrm{Cu}-\mathrm{Br}$ distances in the square-pyramidal examples are 2.543 and 2.430 $\AA$, respectively, revealing a 0.113 Å elongation for axial bonds. In complex 1, the bromo ligand is located on the equatorial plane with a bond length of 2.3974(3) $\AA$ which is shorter than its analogues average.

In the crystal structure of 2 , the $\mathrm{N}_{2} \mathrm{O}_{2}$-donor HEAC forms three five-membered non-planar chelate rings. The angle

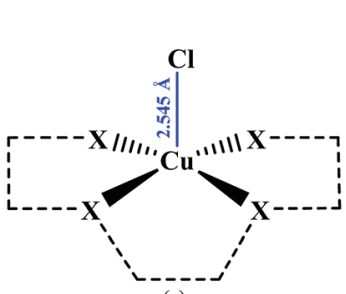

(a)

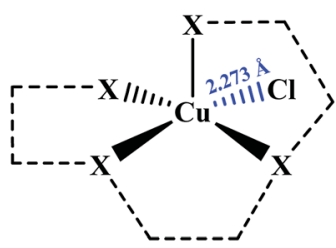

(b)
Scheme 2 Different types of the analogues of the complex 1.

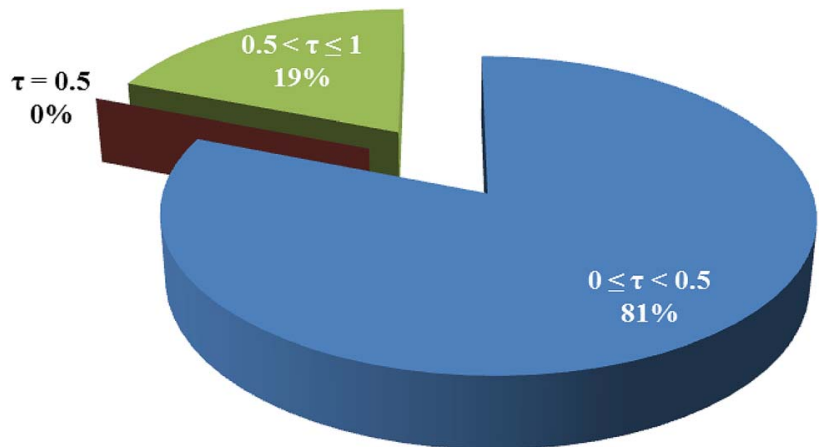

Fig. 3 Percentage of square-pyramidal and trigonal bi pyramidal geometries around the copper atom among the analogues of the complex 1.

between mean planes through the two equatorial chelate rings and also between axial and equatorial chelate rings is 7.62(9) and $86.10(8)^{\circ}$, respectively, confirming a similar coordination geometry of HEAC in complexes 1 and 2. This complex has four chiral centers (two carbon and two nitrogen atoms) and contain a racemic mixture of $R, R, R, S$ and $S, S, S, R$ isomers in alternate layers.

3.2.3. Crystal structure of $\left[\mathrm{Zn}(\mathrm{HEAC}) \mathrm{Cl}_{2}\right]$ (3). X-ray analysis of complex 3 (Fig. 6) revealed that the structure exhibits a five coordinate $\mathrm{Zn}$ (II) center bound to the HEAC ligand, which in this case is tridentate, along with two chloro ligands. The $\tau$ value is 0.61 , confirming a trigonal bipyramidal geometry (Fig. 6 and 7). A structural study of the CSD database revealed that this geometry is not common among the zinc complexes with $\mathrm{CN}=$ 5 with the most common geometry for such complexes being square-pyramidal (64\%), as was observed for copper complexes with the same coordination number. In this geometry two chloro ligands are located on the equatorial plane along with the N1 atom (Scheme 1) of the HEAC ligand, with the two axial positions being occupied by the $\mathrm{O} 1$ and $\mathrm{N} 2$ atoms (Scheme 1). The ethanolic arm of the HEAC does not participate in coordination and is parallel with the equatorial plane, modelled as disordered over two positions. Of the two $\mathrm{Cu}-\mathrm{N}$ distances, the

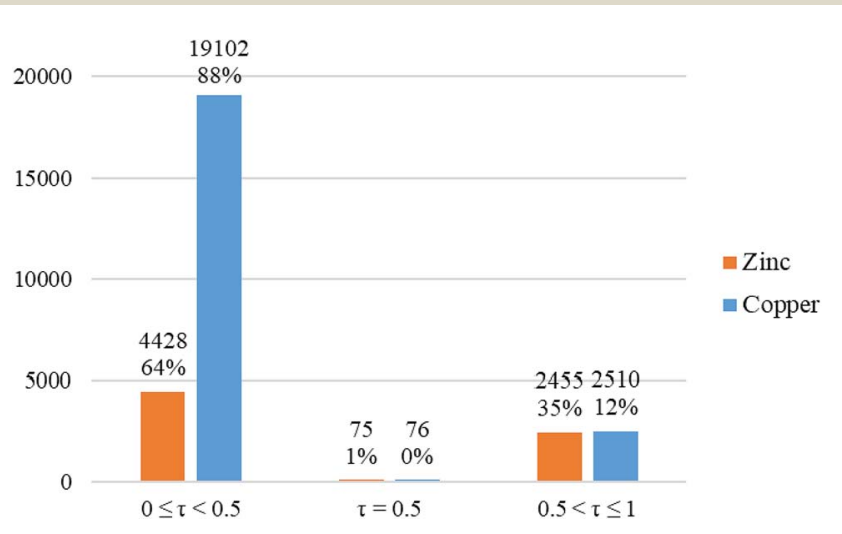

Fig. 4 Column chart of the percentage of different geometries around the penta-coordinated copper (blue columns) and zinc (orange columns) atoms in the CSD database. 


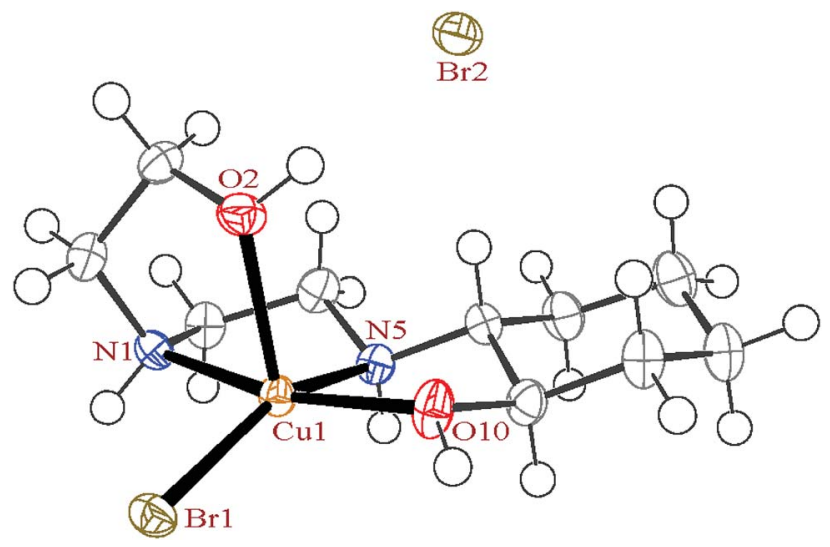

Fig. 5 The ortep diagram of the molecular structure of the complex 2. The ellipsoids are drawn at the $50 \%$ probability level.

axial one is 0.082 (5) $\AA$ longer than the equatorial one, owing to the elongation down the $z$-axis.

The HEAC ligand in 3 acts as $\mathrm{N}_{2} \mathrm{O}$-donor to the zinc atom and forms two five-membered non-planar chelate rings in direction of the axial bonds. Each tridentate ligand can be coordinate to the metal in facial or meridional formations. In the mer form there are two $90^{\circ}$ angles, one $180^{\circ}$ angle, whereas in fac there are three $90^{\circ}$ angles. In 3, two angles of coordinated HEAC are deviating from $90^{\circ}$ due the chelating bite angle, while the third one is about $157.2^{\circ}$, confirming $m e r$ form $\left(135^{\circ}\right.$, exactly half way between $f a c$ and $m e r) .{ }^{51,52}$ The complex $\mathbf{3}$, has four chiral centers (two carbon and two nitrogen atoms) and contain a racemic mixture of $R, R, R, S$ and $S, S, S, R$ isomers in alternate layers.

3.2.4. Crystal network interactions. In the crystal networks of 1-3 (Fig. 2 and 7) intermolecular $\mathrm{N}-\mathrm{H} \cdots \mathrm{X}$ (X: Cl (1, 3), $\mathrm{Br}(\mathbf{2}))$ and $\mathrm{O}-\mathrm{H} \cdots \mathrm{X}(\mathrm{X}: \mathrm{Cl}(\mathbf{1}, 3), \mathrm{Br}(2))$ hydrogen bonds appear between different moieties. In this way the halide ions act as proton acceptors and the nitrogen and oxygen atoms as proton donors. The free halide ions in $\mathbf{1}$ and $\mathbf{2}(\mathrm{Cl} 2$ and $\mathrm{Br} 2)$ play a more important role in the crystal network expansion than the coordinated halides (Cl1, Br1) owing to them forming intermolecular hydrogen bonds.

In the crystal packing of the complexes, the $\mathrm{N}-\mathrm{H} \cdots \mathrm{Cl}$ and $\mathrm{O}-$ $\mathrm{H} \cdots \mathrm{Cl}$ hydrogen bonds in $1, \mathrm{~N}-\mathrm{H} \cdots \mathrm{Br}$ and $\mathrm{O}-\mathrm{H} \cdots \mathrm{Br}$ in 2 and $\mathrm{N}-$ $\mathrm{H} \cdots \mathrm{Cl}$ in 3 participate in the formation of very different hydrogen bond motifs such as $\mathrm{R}_{3}^{4}(14), \mathrm{R}_{3}^{6}(18)$ and $\mathrm{R}_{4}^{6}(20)$ in 1 and 2 (Fig. 2 and 7) and $R_{2}^{2}(8), R_{4}^{6}(20), R_{5}^{6}(22)$ and $R_{6}^{6}(24)$ in 3 between adjacent complexes..$^{51,53}$

The total intermolecular interaction energies of one molecule of $\mathbf{1}$ and 2 were calculated using Mercury ${ }^{54}$ and its CSDmaterials tool. ${ }^{38,55}$ For this, the sum of the intermolecular interactions energies in a molecular packing shell containing 100 molecules around one molecule of $\mathbf{1}$ and 2 were calculated to be $-\mathbf{1 2 9 . 7 6}$ (for cationic unit of $\mathbf{1}$ ), 58.35 (for anionic unit of 1), -139.709 (for cationic unit of 2) and $40.63 \mathrm{~kJ} \mathrm{~mol}^{-1}$ (for anionic unit of 2) (Fig. 8), confirming that one molecule of complex 2 is more stabilized in the solid state, by its network interactions, than $\mathbf{1}$. Also the cationic complex unit in $\mathbf{1}$ and $\mathbf{2}$ is more stabilized than the anionic species by intermolecular interactions. For the cationic unit of complex 1, 44\% (Cu1 enantiomer) of the total energy is corresponding to the interactions with its 13 closest neighboring molecules (Fig. 8). This value for 2 with the same condition is $45 \%$. The interactions between one molecule of the complexes $\mathbf{1}$ and 2 with three closest molecules in distance range of 3.5-5.5 $\AA$, increase the energy component of the molecule by +68.35 and

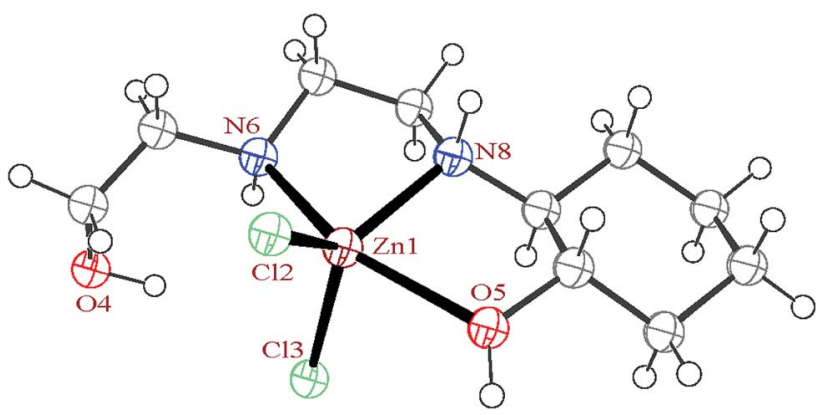

Fig. 6 The ortep diagram of the molecular structure of the complex 3 . The ellipsoids are drawn at the 50\% probability level.

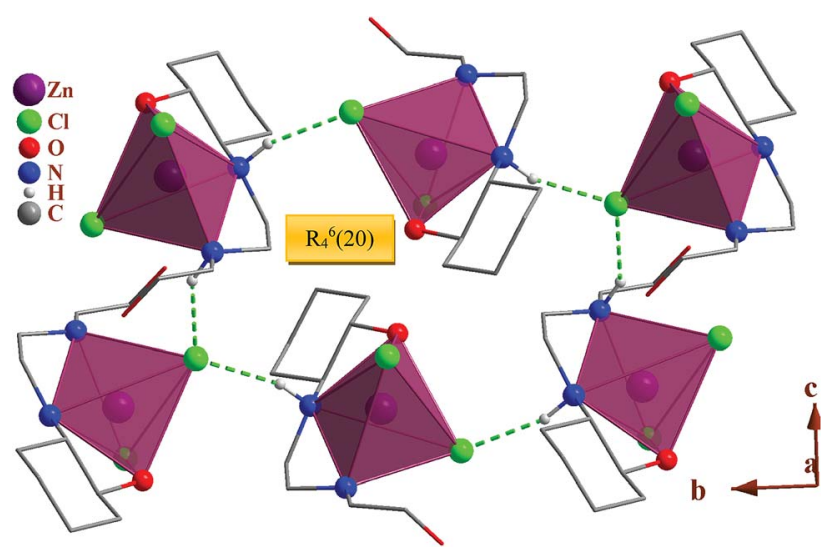

Fig. 7 Packing of the complex 3, showing the hydrogen bonds. Only the hydrogen atoms involved in hydrogen bonding are shown. Each $\mathrm{ZnN}_{2} \mathrm{OCl}_{2}$ unit is shown as trigonal bi pyramid. Also $\mathrm{R}_{4}^{6}(20)$ hydrogen bond motifs between six complexes 3 is shown.

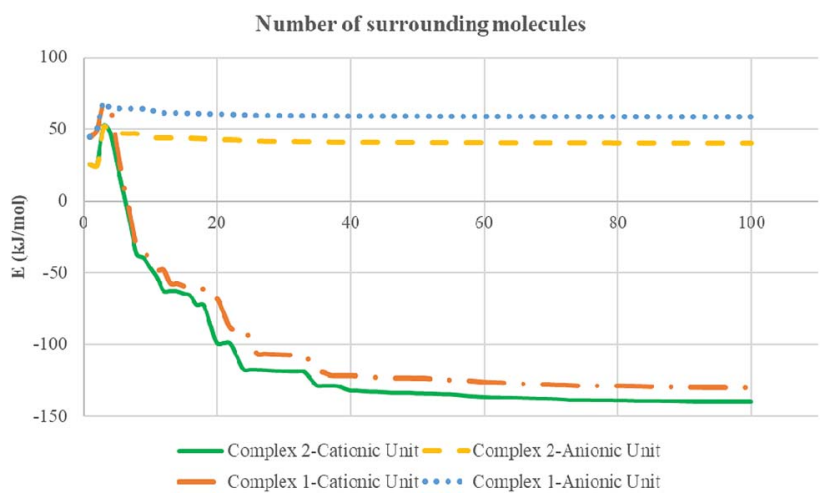

Fig. 8 Variation diagram of total intermolecular interactions energy $(E)$ for complexes 1 and 2 with increasing the number of surrounding molecules. 
$+51.51 \mathrm{~kJ} \mathrm{~mol}^{-1}$, respectively, whilst other interactions decrease the energy level of the studied units.

\subsection{PXRD and SEM studies of nano complexes}

Fig. 9-11 shows both the simulated PXRD patterns obtained from the single crystal X-ray data of complexes 1-3 and that obtained experimentally from the nano complexes 1-3 prepared by the sonochemical process. The experimental data matched well, with slight variations in $2 \theta$ values. This indicates that the nano complexes 1-3 obtained by the sonochemical process possess an identical structure to the larger crystals. Estimated from the Sherrer formula for the calculation of particle sizes from the PXRD peaks $(L=K \lambda /(\beta \cos \theta)$, where $L$ is the average crystallite size in $\mathrm{nm}, \beta$ is the breadth of the observed diffraction line at its half-maximum intensity, $K$ is the so-called 'shape factor', and $\lambda$ is the wavelength of the X-ray radiation $(\lambda=0.15406 \mathrm{~nm}))$, the average sizes of the particles were calculated to be $42.85,36.078$ and $43.55 \mathrm{~nm}$ for complexes 1-3, which is in agreement with the values obtained from the SEM images (Fig. 9-11).
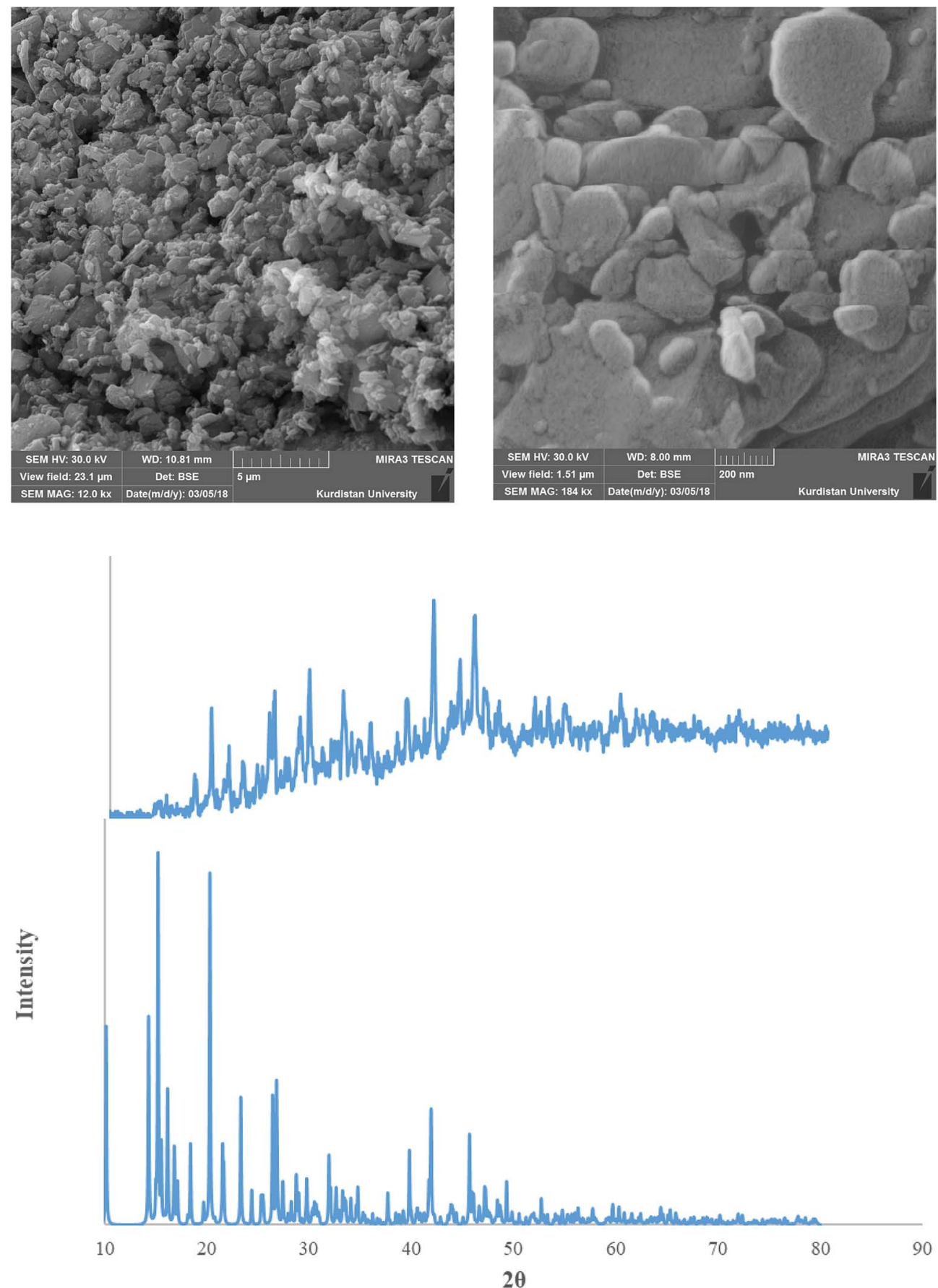

Fig. 9 PXRD pattern (middle) and SEM images (upper) of the nano complex 1 . Also single crystal X-ray diffraction pattern of 1 (under) is presented. 

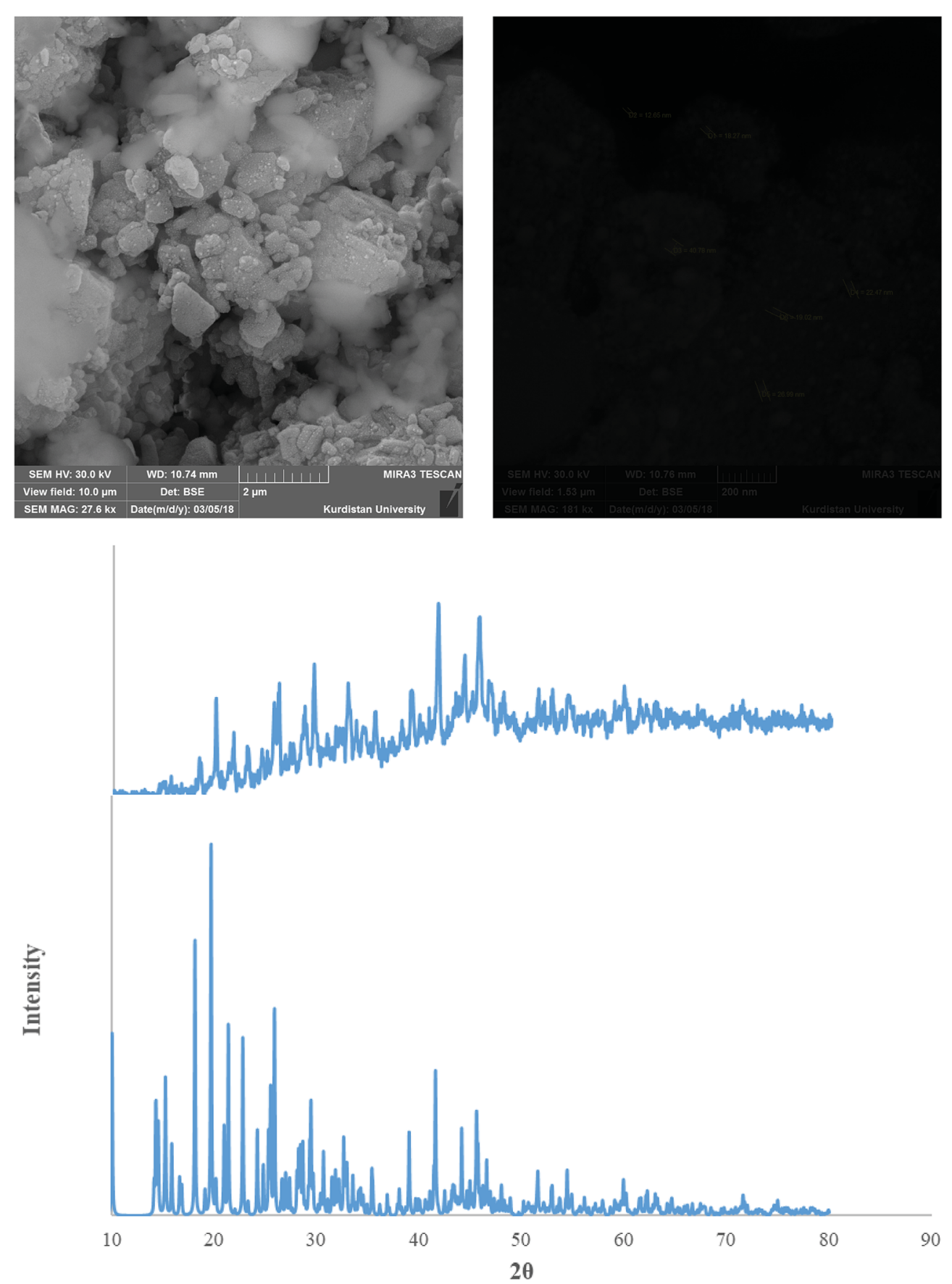

Fig. 10 PXRD pattern (middle) and SEM images (upper) of the nano complex 2. Also single crystal X-ray diffraction pattern of 2 (under) is presented.

\subsection{Theoretical studies}

For comparing the energy levels of the complexes for one isolated molecule, DFT calculations were performed. The data revealed that the order of thermodynamic stability of the optimized complexes is $\mathbf{1}^{\text {opt }}>2^{\text {opt }}>3^{\text {opt }}$. The complex $1^{\text {opt }}$ is -2235.98 and $-81890.18 \mathrm{kcal} \mathrm{mol}^{-1}$ thermodynamically more stable than the $2^{\text {opt }}$ and $3^{\text {opt }}$, respectively which shows that the chloro ligand of $\mathbf{1}^{\text {opt }}$ stabilizes the copper atom significantly more than the bromo ligand does.
For studying the charge distribution before and after complexation, a NBO analysis was done on the free HEAC ligand and its complexes (Table 4). The results reveal that the calculated charge on the metal atoms are in the range of 0.79-1.13 (Table 4) and lower than the formal charge $(+2)$ owing to the electron donation of the ligand during complexation. Based on the calculated total charge values, the charge on the nitrogen, carbon and oxygen atoms in the optimized complexes does not have significant variation with 

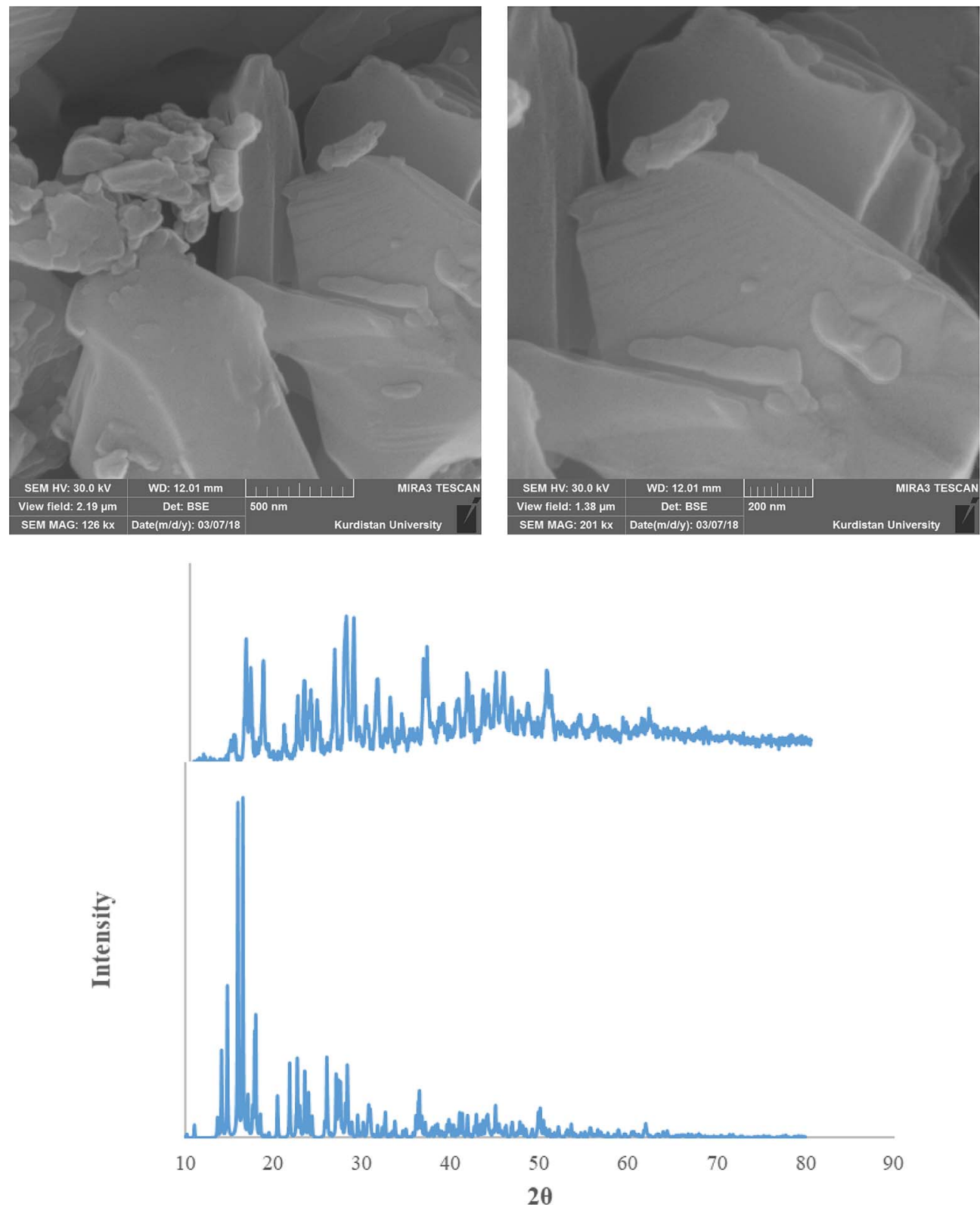

Fig. 11 PXRD pattern (middle) and SEM images (upper) of the nano complex 3 . Also single crystal X-ray diffraction pattern of 3 (under) is presented.

respect to the free ligand, whilst the total charge on the hydrogen atoms is more positive than in the free ligand (Table 4). This observation reveals that the hydrogen atoms play an important role in electron donation toward metal atom, thus decreasing the charge of the copper and zinc atoms.

Table 4 The NBO analysis results for the complexes 1-3 and HEAC. The values are the total of charge on the similar atoms. The values of parentheses show the variation of charge on the atoms after coordination

\begin{tabular}{lllllll}
\hline & & & & & & \\
& $\mathrm{H}$ & $\mathrm{N}$ & $\mathrm{O}$ & Bonded halide & $\begin{array}{l}\text { Non-bonded } \\
\text { halide }\end{array}$ & - \\
\hline HEAC & -2.27 & 5.45 & -1.51 & -1.67 & - & - \\
Complex 1 & $-2.32(-0.05)$ & $5.91(+0.46)$ & $-1.48(+0.03)$ & $-1.60(+0.07)$ & -0.55 & -0.78 \\
Complex 2 & $-2.31(-0.04)$ & $5.91(+0.46)$ & $-1.49(+0.02)$ & $-1.60(+0.07)$ & -0.50 & -0.80 \\
Complex 3 & $-2.29(-0.02)$ & $5.77(+0.32)$ & $-1.61(-0.10)$ & $-1.65(+0.02)$ & -1.34 & 0.79 \\
& & & & & $(-0.67$ per each chloride)
\end{tabular}


Table $5 \mathrm{HOHO}$, LUMO orbitals and total energy for the optimized structures of HEAC and complexes $1-3^{\mathrm{opt}}$

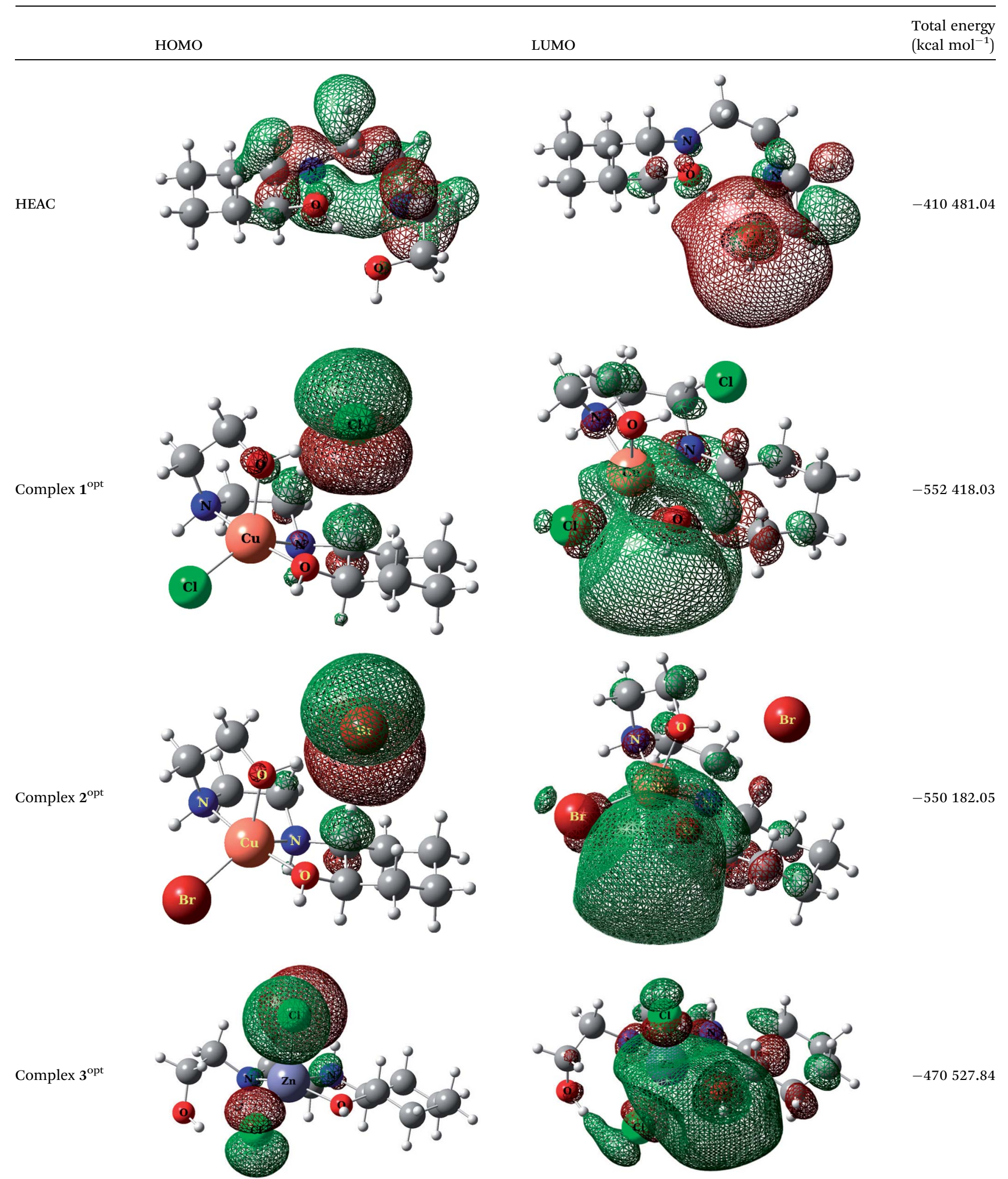


Table 6 The calculated fitness values for the HEAC ligand and complexes 1-3

\begin{tabular}{llllllllr}
\hline & BRAF-kinase & CatB & DNA-gyrase & HDAC7 & rHA & RNR & TrxR & TS \\
\hline HEAC & 36.56 & 23.96 & 38.05 & 47.08 & 39.30 & 34.89 & 38.37 & 36.92 \\
Complex 1 & 36.89 & 21.89 & 34.57 & 38.52 & 38.30 & 33.80 & 44.26 & 34.24 \\
Complex 2 & 38.28 & 21.58 & 35.34 & 39.53 & 40.07 & 34.37 & 45.84 & 35.34 \\
Complex 3 & 37.80 & 22.70 & 37.00 & 40.06 & 37.06 & 35.18 & 43.16 & 35.38 \\
\hline
\end{tabular}

In the optimized HEAC, the HOMO is mostly delocalized on the ethylene diamine moiety while the LUMO is delocalized on the oxygen atom of the ethanolic arm of the ligand (Table 5). In the structure of the HOMO and LUMO of the complexes, the metal atom and halide ions play the main role. In $\mathbf{1}^{\mathrm{opt}}$ and $2^{\mathrm{opt}}$, the HOMO is mostly delocalized on the non-bonded halide ions whilst the LUMO is on the metal center. In $3^{\text {opt }}$, the metal atom is host to a significant portion of the LUMO and coordinated chloro ligand holds the majority of the HOMO.

In the isolated molecules of $\mathbf{1}^{\mathrm{opt}}, 2^{\mathrm{opt}}$ and $3^{\mathrm{opt}}$, the metal atoms have $\tau$ values of $0.56,0.57$ and 0.10 , respectively, revealing favored trigonal bi pyramidal geometry for the copper complexes and square-pyramidal geometry for zinc complex. These results are in contrast with the experimentally obtained solid state structures, suggesting that perhaps the intermolecular interactions affect the geometry around the metal center in solid phase.

\subsection{Docking studies}

For predicting the biological activities of the HEAC ligand and complexes 1-3, interactions of these compounds with nine macromolecule receptors, using Gold ${ }^{39}$ docking software, were studied. The Gold docking results are reported in terms of the values of fitness which means that the higher fitness the better the docked interaction of the compounds. ${ }^{27}$ The results of the docking presented in this work are the best binding results out of the ten favorites predicted by Gold.

The general features from the Gold docking prediction (Table 6) confirm biologically active properties for all of the studied compounds. The best predicted target for HEAC is HDAC7, whilst for the studied complexes it was the TrxR target. Comparing the GOLDScore fitness values for the ligand and complexes showed that in some cases the ligand had a better interaction with the biomacromolecules (CatB, DNA-gyrase, HDAC7, TS) whilst the rest of the proteins (BRAF-kinase, rHA, RNR, TrxR, Top II) preferred the complexes. A fitness value comparison between studied complexes showed the general trend $\mathbf{3}>\mathbf{2}>\mathbf{1}$ in their binding ability towards proteins. Based on this result we can conclude that the zinc atom increases the binding ability of the HEAC to proteins better than the copper atom. Also the bromide ions of complex 2 are more efficient than chloride ions (1) in interaction toward biomacromolecules. The docking results of the interaction between the ligand and complex 1 with BRAF kinase protein are shown in the Fig. 12 and 13, respectively. In addition to the alcohol and amino moieties in the structures, the bonded and non-bonded chloride (1) and bromide (2) ions participate in hydrogen bonding with proteins.

\subsection{Biological screening}

In addition to the docking studies, the in vitro cytotoxicities of HEAC and its complexes with copper $(\mathbf{1}, 2)$ and zinc $(3)$ on the human cancer cell line K562 were evaluated experimentally. Results are expressed as $\mathrm{IC}_{50}$ values and are summarized in Table 7. The MTT assay showed that tested compounds exerted significant cytotoxic effects against K562 cell lines. For the studied compounds, the cytotoxic effects of the complex $\mathbf{1}$ is higher than the free ligand; showing that the biological activity of HEAC is increased upon binding to a copper atom containing a chloro ligand. This study also revealed that in addition to the nature of the coordinated metal atom, the type of the halide ions on the metal center affected the cytotoxicity of the

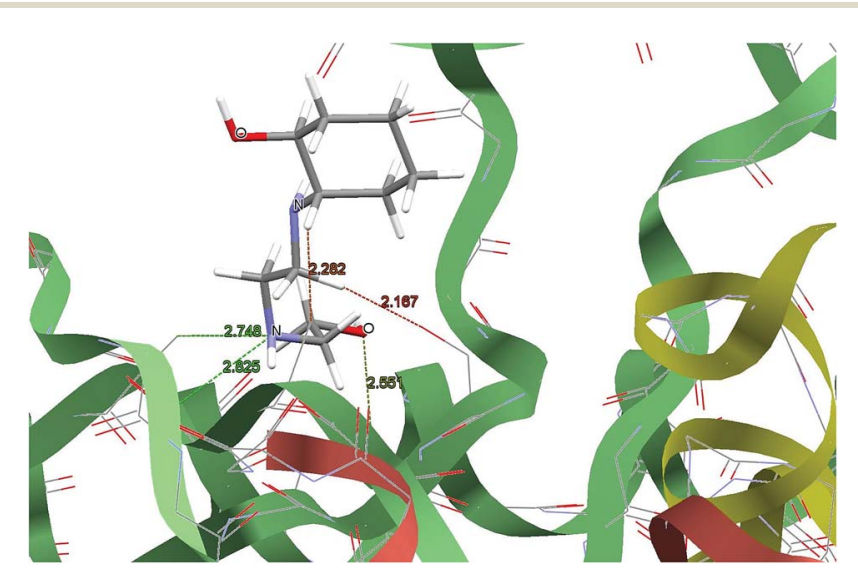

Fig. 12 Docking study results, showing the interaction between HEAC ligand and BRAF kinase protein.

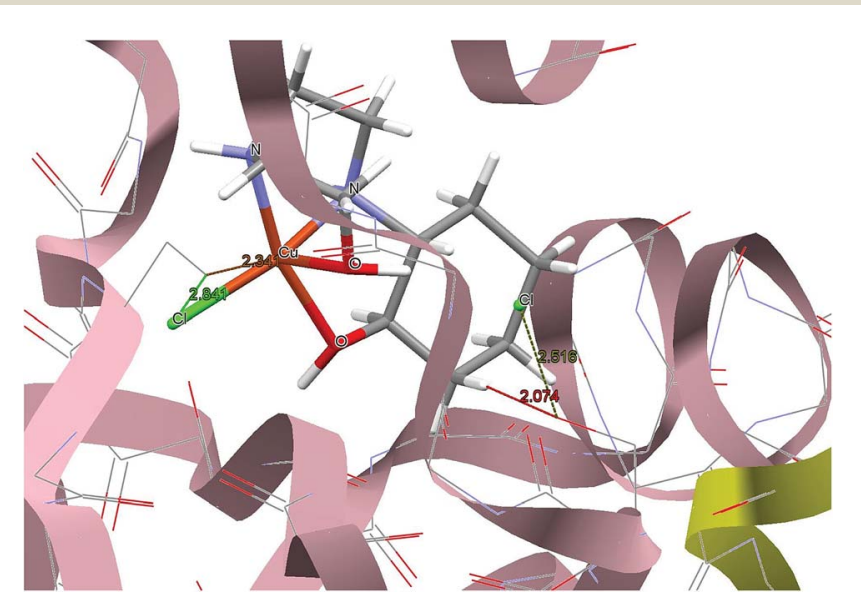

Fig. 13 Docking study results, showing the interaction between the complex 1 and BRAF kinase protein. 
Table 7 Concentrations of HEAC and its complexes 1-3 that induced a $50 \%$ decrease in $\mathrm{K} 562$ cell survival (expressed as $\left.I C_{50}\left(\mu \mathrm{g} \mathrm{ml}^{-1}\right)\right)$. The compounds were incubated with cells for 24,48 and $72 \mathrm{~h}$. IC $\mathrm{C}_{50}$ values are expressed as the mean \pm SD determined from three independent experiments

\begin{tabular}{lrrr}
\hline Compounds & \multicolumn{1}{c}{ 24 h } & \multicolumn{1}{c}{$48 \mathrm{~h}$} & \multicolumn{1}{c}{$72 \mathrm{~h}$} \\
\hline HEAC & $11.500 \pm 0.430$ & $11.750 \pm 0.423$ & $11.560 \pm 0.541$ \\
Complex 1 & $9.687 \pm 0.174$ & $9.471 \pm 0.327$ & $7.923 \pm 0.031$ \\
Complex 2 & $16.090 \pm 0.194$ & $16.612 \pm 0.353$ & $17.280 \pm 0.211$ \\
Complex 3 & $18.640 \pm 0.323$ & $18.510 \pm 0.114$ & $19.195 \pm 0.141$
\end{tabular}

compounds. Complexes $\mathbf{1}$ and $\mathbf{2}$ are isostructural, with the only difference being the halide atoms, however this resulted in the $\mathrm{IC}_{50}$ value of the complex containing the chloro ligand be about two times lower than the bromo ligand. The order of the cytotoxicity for all studied compounds is $1>\mathrm{HEAC}>2>3$. The $\mathrm{IC}_{50}$ values for different incubation time $(24-72 \mathrm{~h})$ are similar; showing that the cytotoxicity effect of all compounds is insensitive to the mentioned parameter.

We also investigated the type of cell death induced by the compounds in K562 cells, based on the analysis of morphological characteristics of the cells after the double staining of with acridine orange (AO) and propidium iodide (PI) by fluorescence microscopy. Morphological features of apoptosis such as chromatin condensation, nuclear fragmentation and alterations in the size and the shape of cells were observed after $48 \mathrm{~h}$ treatment with $\mathrm{IC}_{50}$ concentrations of the compounds. Also, the features of late apoptosis were

Table 8 Morphological changes of $\mathrm{K} 562$ cells after $48 \mathrm{~h}$ treatment with $\mathrm{IC}_{50}$ concentrations of complexes $1-3$. The cells were stained with acridine orange and propidium iodide and examined by fluorescence microscope. The presence of early and late apoptosis along with the necrosis of K562 cells could be seen. (a): Complex 1, (b): Complex 2, (c): Complex 3

\begin{tabular}{lll}
\hline Column graph & Normal cells & Cells after exposure to compounds
\end{tabular}

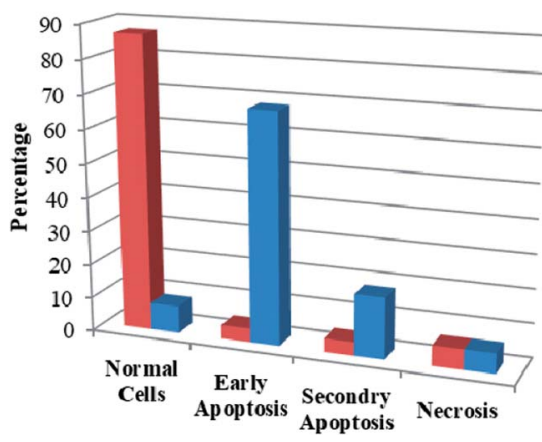

(a)

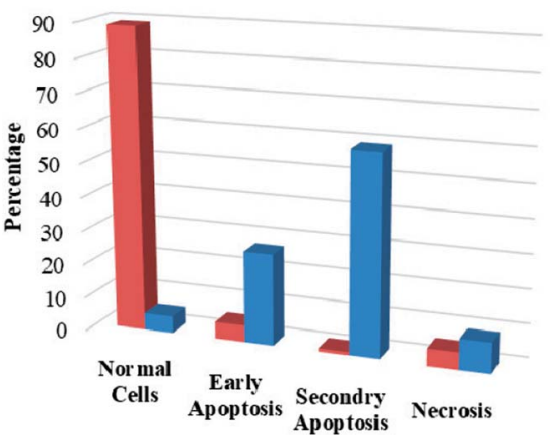

(b)

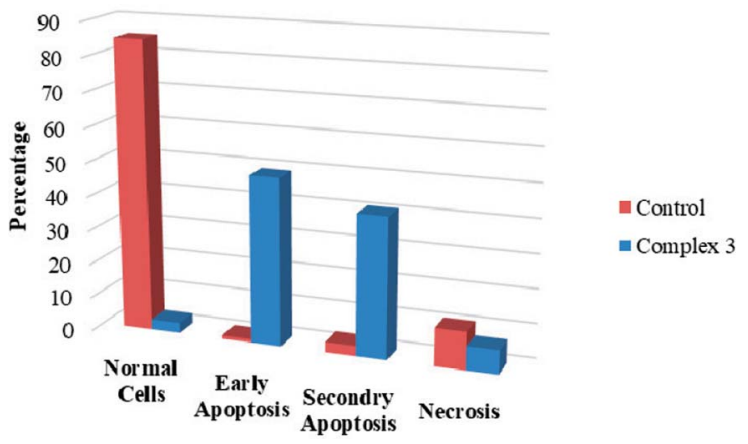

- Control - Complex 2
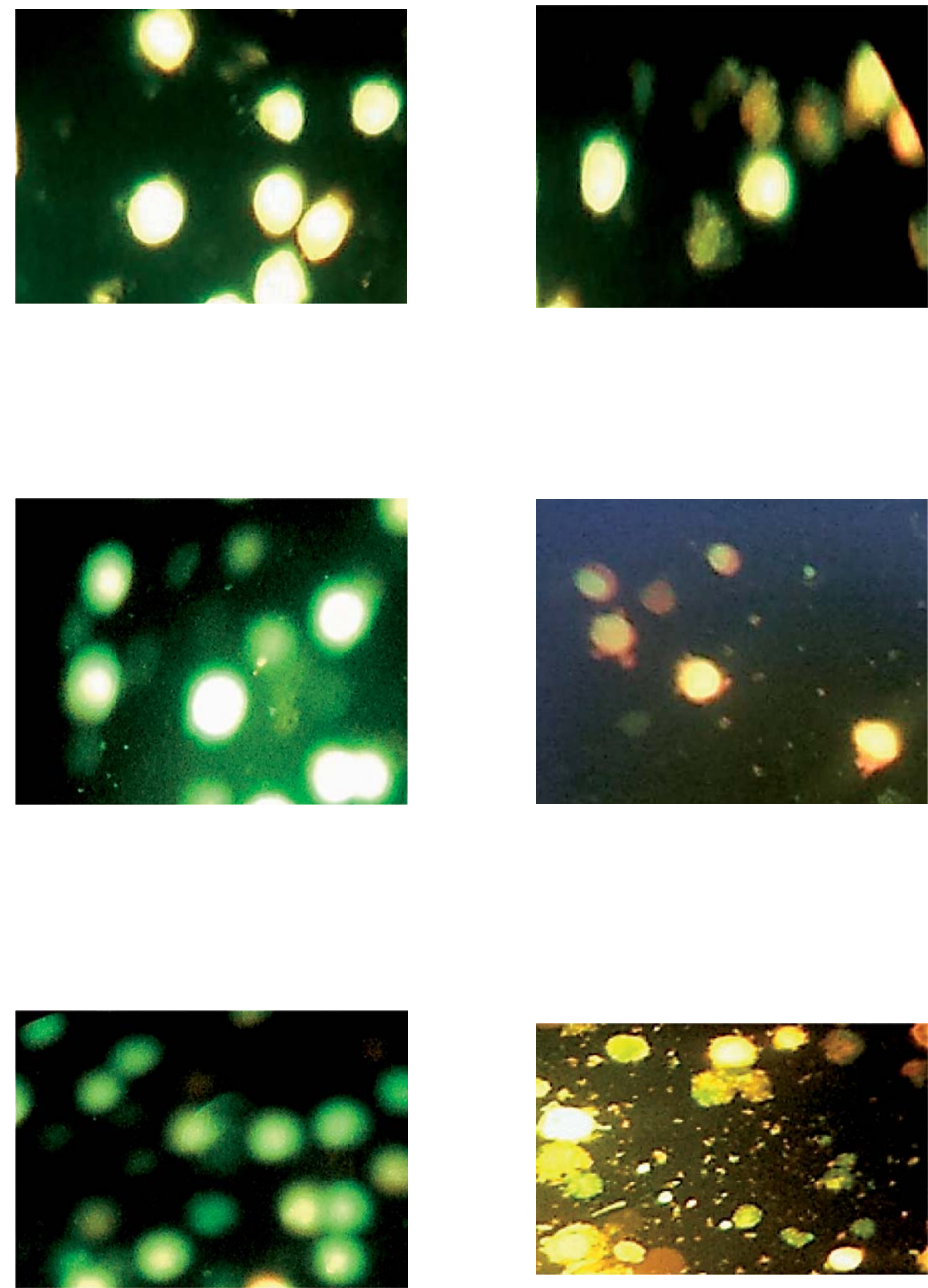

(c) 
clearly expressed; the DNA was fragmented and stained orange and red. As shown in Table 8, the percentage of early apoptotic cells after treatment with complex 1 for $48 \mathrm{~h}$ is higher than the other compounds. Of the three tested compounds, the ability of complex 2 to induce secondary apoptosis in $\mathrm{K} 562$ cells is significant.

\section{Conclusions}

In this work, three complexes of copper and zinc, $[\mathrm{Cu}(\mathrm{HEAC}) \mathrm{Cl}] \mathrm{Cl}$ (1), [Cu(HEAC)Br] Br (2), [Zn(HEAC) $\left.\mathrm{Cl}_{2}\right]$ (3); HEAC: 2-(2-(2-hydroxyethylamino)ethylamino)cyclohexanol, were synthesized and their spectral (IR, UV-Vis, ${ }^{1} \mathrm{H}$ NMR) and structural (single crystal X-ray diffraction) properties were investigated. Also nanoparticles 1-3 for anticancer studies were prepared under ultrasonic irradiation and the particles size were analyzed by PXRD and SEM. In the isostructural complexes $\mathbf{1}$ and 2, the metal atom has squarepyramidal geometry which is formed by a tetradentate $\mathrm{N}_{2} \mathrm{O}_{2}-$ donor (HEAC) and a chloro ligand. In this geometry, the axial $\mathrm{Cu}-$ $\mathrm{O}$ bond length is elongated with respect to the similar equatorial one. The zinc atom in complex $\mathbf{3}$ has the same coordination number to $\mathbf{1}$ and $\mathbf{2}$ but possesses a different geometry, trigonal bipyramidal. In this structure, the HEAC shows a different coordination manner (mer- $\mathrm{N}_{2} \mathrm{O}$-donor) than the others. A structural study of the CSD database revealed that the common geometry around the penta-coordinated copper and zinc atoms is squarepyramidal ( $88 \%$ and $64 \%$, respectively). In the crystal packing of the complexes, the halide ions participate in the formation of very different hydrogen bond motifs between adjacent complexes. The docking studies on all synthesized compounds showed that they are biologically active and can interact with the nine biomacromolecules (BRAF kinase, CatB, DNA gyrase, HDAC7, rHA, RNR, TrxR, TS and Top II). The best predicted targets for the free ligand is HDAC7, whilst for the complexes it is TrxR. The biological assay of the compounds on the human cancer cell line K562 confirmed the docking results. Among the complexes, the cytotoxic effects of complex 1 was higher than the free ligand with the order of cytotoxicity being $\mathbf{1}>$ HEAC $>\mathbf{2}>3$. Complexes 1 and 2 can induce early apoptosis (68\%) and secondary apoptosis (59\%) in K562 cells better than the others, respectively. The difference between theoretical (docking) and experimental (biological assay) results revealed that the anticancer activities of the studied compounds may be related to the other mechanisms than the interaction with these nine protein targets (for example DNA binding). The NBO analysis of the compounds revealed that among the hydrogen, carbon, nitrogen and oxygen atoms of the coordinated ligands, the hydrogen atoms act as electron donors and decrease the charge of the metal atom. The order of thermodynamic stability of the optimized complexes is determined as $\mathbf{1}^{\mathrm{opt}}$ $>2^{\text {opt }}>3^{\text {opt }}$ by DFT calculations.

\section{Conflicts of interest}

There are no conflicts to declare.

\section{Acknowledgements}

This study was supported financially by the Iran National Science Foundation (INSF).

\section{References}

1 R. Yendapally and R. E. Lee, Bioorg. Med. Chem. Lett., 2008, 18, 1607-1611.

2 I. Declerck, B. Himpens, G. Droogmans and R. Casteels, Pflugers Arch., 1990, 417, 117-119.

3 M. M. Weinberger, Pediatr. Clin. North Am., 1975, 22, 121127.

4 S. J. Kwon and S. Y. Ko, Tetrahedron Lett., 2002, 43, 639-641. 5 W. H. Frishman, Circulation, 2003, 107, e117-e119.

6 D. Nash, Clin. Cardiol., 1990, 13, 764-772.

7 H.-X. Wei, D. Lu, V. Sun, J. Zhang, Y. Gu, P. Osenkowski, W. Ye, D. J. Selkoe, M. S. Wolfe and C. E. Augelli-Szafran, Bioorg. Med. Chem. Lett., 2016, 26, 2133-2137.

8 D. J. Ager, I. Prakash and D. R. Schaad, Chem. Rev., 1996, 96, 835-876.

9 A. G. Myers, B. H. Yang, H. Chen, L. McKinstry, D. J. Kopecky and J. L. Gleason, J. Am. Chem. Soc., 1997, 119, 6496-6511.

10 A. Russo and A. Lattanzi, Eur. J. Org. Chem., 2008, 2767-2773.

11 A. J. Hunt, E. H. Sin, R. Marriott and J. H. Clark, ChemSusChem, 2010, 3, 306-322.

12 J. E. Rainbolt, P. K. Koech, C. R. Yonker, F. Zheng, D. Main, M. L. Weaver, J. C. Linehan and D. J. Heldebrant, Energy Environ. Sci., 2011, 4, 480-484.

13 T. Werner and N. Tenhumberg, J. CO2 Util., 2014, 7, 39-45.

14 K. C. Rao, Y. Arun, K. Easwaramoorthi, C. Balachandran, T. Prakasam, T. E. Yuvaraj and P. Perumal, Bioorg. Med. Chem. Lett., 2014, 24, 3057-3063.

15 S. Vanguru, L. Jilla, Y. Sajja, R. Bantu, L. Nagarapu, J. B. Nanubolu, B. Bhaskar, N. Jain, S. Sivan and V. Manga, Bioorg. Med. Chem. Lett., 2017, 27, 792-796.

16 H. Takahashi, M. Hattori, M. Chiba, T. Morimoto and K. Achiwa, Tetrahedron Lett., 1986, 27, 4477-4480.

17 F. A. Davis, M. S. Haque and R. M. Przeslawski, J. Org. Chem., 1989, 54, 2021-2024.

18 G. Li, H. T. Chang and K. B. Sharpless, Angew. Chem., 1996, 108, 449-452.

19 G. B. Fisher, C. T. Goralski, L. W. Nicholson, D. L. Hasha, D. Zakett and B. Singaram, J. Org. Chem., 1995, 60, 20262034.

20 M. Hakimi, Z. Mardani, K. Moeini and M. A. Fernandes, J. Coord. Chem., 2012, 65, 2221-2233.

21 T. Baskaran, A. Joshi, G. Kamalakar and A. Sakthivel, Appl. Catal., A, 2016, 524, 50-55.

22 C. Shi, C. Ren, E. Zhang, H. Jin, X. Yu and S. Wang, Tetrahedron, 2016, 72, 3839-3843.

23 M. Anjomshoa, M. Torkzadeh-Mahani, E. Dashtrazmi and M. Adeli-Sardou, J. Fluoresc., 2016, 26, 545-558.

24 M. Sahlabadi, M. Daryanavard, H. Hadadzadeh and Z. Amirghofran, J. Mol. Struct., 2018, 1155, 450-456.

25 M. Shebl, M. Saif, A. I. Nabeel and R. Shokry, J. Mol. Struct., 2016, 1118, 335-343. 
26 F. Marandi, K. Moeini, F. Alizadeh, Z. Mardani, C. K. Quah and W.-S. Loh, Z. Naturforsch., 2018, 73(6), 369-375,.

27 A. A. Adeniyi and P. A. Ajibade, Molecules, 2013, 18, 37603778.

28 C. B. Lozzio and B. B. Lozzio, Blood, 1975, 45, 321-334.

29 M. Hakimi, Z. Mardani, K. Moeini, F. Mohr and M. A. Fernandes, Polyhedron, 2014, 67, 27-35.

30 A. K. Abu Al-Nasr and R. M. Ramadan, Spectrochim. Acta, Part A, 2013, 105, 14-19.

31 G. Sheldrick, Acta Crystallogr., Sect. A: Found. Adv., 2015, 71, 3-8.

32 G. Sheldrick, Acta Crystallogr., Sect. C: Struct. Chem., 2015, 71, 3-8.

33 L. J. Farrugia, J. Appl. Crystallogr., 1997, 30, 565.

34 M. N. Burnett and C. K. Johnson, Ortep-III, Report ORNL6895, Oak Ridge National Laboratory, Oak Ridge, Tennessee, U.S., 1996.

35 G. Bergerhof, M. Berndt and K. Brandenburg, J. Res. Natl. Inst. Stand. Technol., 1996, 101, 221-225.

36 M. J. Frisch, G. W. Trucks, H. B. Schlegel, G. E. Scuseria, M. A. Robb, J. R. Cheeseman, G. Scalmani, V. Barone, B. Mennucci, G. A. Petersson, H. Nakatsuji, M. Caricato, X. Li, H. P. Hratchian, A. F. Izmaylov, J. Bloino, G. Zheng, J. L. Sonnenberg, M. Hada, M. Ehara, K. Toyota, R. Fukuda, J. Hasegawa, M. Ishida, T. Nakajima, Y. Honda, O. Kitao, H. Nakai, T. Vreven, J. A. Montgomery Jr, J. E. Peralta, F. Ogliaro, M. J. Bearpark, J. Heyd, E. N. Brothers, K. N. Kudin, V. N. Staroverov, R. Kobayashi, J. Normand, K. Raghavachari, A. P. Rendell, J. C. Burant, S. S. Iyengar, J. Tomasi, M. Cossi, N. Rega, N. J. Millam, M. Klene, J. E. Knox, J. B. Cross, V. Bakken, C. Adamo, J. Jaramillo, R. Gomperts, R. E. Stratmann, O. Yazyev, A. J. Austin, R. Cammi, C. Pomelli, J. W. Ochterski, R. L. Martin, K. Morokuma, V. G. Zakrzewski, G. A. Voth, P. Salvador, J. J. Dannenberg, S. Dapprich, A. D. Daniels, Ö. Farkas, J. B. Foresman, J. V. Ortiz, J. Cioslowski and D. J. Fox, Gaussian, Inc., Wallingford, CT, USA, 2009.
37 J. P. Perdew, Phys. Rev. B: Condens. Matter Mater. Phys., 1986, 33, 8822-8824.

38 A. Gavezzotti, Acc. Chem. Res., 1994, 27, 309-314.

39 G. Jones, P. Willett, R. C. Glen, A. R. Leach and R. Taylor, J. Mol. Biol., 1997, 267, 727-748.

40 M. Hakimi, Z. Mardani, K. Moeini, F. Mohr and M. A. Fernandes, Polyhedron, 2014, 67, 27-35.

41 A. W. Addison, T. Rao, J. Reedjik, J. V. Rijn and G. Verschoor, Dalton Trans., 1984, 1349.

42 M. Hakimi, Z. Mardani, K. Moeini and F. Mohr, Polyhedron, 2015, 102, 569-577.

43 S. Roy, P. Mitra and A. K. Patra, Inorg. Chim. Acta, 2011, 370, 247-253.

44 F. H. Allen, Acta Crystallogr., Sect. B: Struct. Sci., 2002, 58, 380-388.

45 M. Hakimi, Z. Mardani, K. Moeini, E. Schuh and F. Mohr, Z. Naturforsch., B: J. Chem. Sci., 2013, 68, 272.

46 M. Hakimi, Z. Mardani, K. Moeini, E. Schuh and F. Mohr, Z. Naturforsch., B: J. Chem. Sci., 2013, 68, 267.

47 B. F. Hoskins and F. D. Whillans, J. Chem. Soc. A, 1970, 123. 48 P. J. Toscano, K. J. Fordon, D. Macherone, S. Liu and J. Zubieta, Polyhedron, 1990, 9, 2375-2383.

49 Y. M. Lee, E. S. Kim, H. J. Kim, H. J. Choi, Y. I. Kim, S. K. Kang and S. N. Choi, Dalton Trans., 2009, 126-133.

50 S. Sarkar, S. Dey, T. Mukherjee, E. Zangrando, M. G. B. Drew and P. Chattopadhyay, J. Mol. Struct., 2010, 980, 94-100.

51 M. Hakimi, Z. Mardani, K. Moeini, F. Mohr and M. A. Fernandes, Polyhedron, 2014, 67, 27-35.

52 M. Hakimi, Z. Mardani, K. Moeini, N. Feizi and F. Mohr, J. Coord. Chem., 2017, 70, 1247-1259.

53 M. Hakimi, K. Moeini, Z. Mardani and F. Mohr, Polyhedron, 2014, 70, 92-100.

54 C. F. Macrae, I. J. Bruno, J. A. Chisholm, P. R. Edgington, P. McCabe, E. Pidcock, L. Rodriguez-Monge, R. Taylor, J. Van De Streek and P. A. Wood, J. Appl. Crystallogr., 2008, 41, 466-470.

55 A. Gavezzotti and G. Filippini, J. Phys. Chem., 1994, 98, 48314837. 